\title{
Methods of Monitoring Cell Fate and Tissue Growth in Three-Dimensional Scaffold-Based Strategies for In Vitro Tissue Engineering
}

Citation for published version (APA):

Leferink, A. M., van Blitterswijk, C. A., \& Moroni, L. (2016). Methods of Monitoring Cell Fate and Tissue Growth in Three-Dimensional Scaffold-Based Strategies for In Vitro Tissue Engineering. Tissue Engineering, 22(4), 265-283. https://doi.org/10.1089/ten.teb.2015.0340

Document status and date:

Published: 01/08/2016

DOI:

10.1089/ten.teb.2015.0340

Document Version:

Publisher's PDF, also known as Version of record

Document license:

Taverne

Please check the document version of this publication:

- A submitted manuscript is the version of the article upon submission and before peer-review. There can be important differences between the submitted version and the official published version of record.

People interested in the research are advised to contact the author for the final version of the publication, or visit the DOI to the publisher's website.

- The final author version and the galley proof are versions of the publication after peer review.

- The final published version features the final layout of the paper including the volume, issue and page numbers.

Link to publication

\footnotetext{
General rights rights.

- You may freely distribute the URL identifying the publication in the public portal. please follow below link for the End User Agreement:

www.umlib.nl/taverne-license

Take down policy

If you believe that this document breaches copyright please contact us at:

repository@maastrichtuniversity.nl

providing details and we will investigate your claim.
}

Copyright and moral rights for the publications made accessible in the public portal are retained by the authors and/or other copyright owners and it is a condition of accessing publications that users recognise and abide by the legal requirements associated with these

- Users may download and print one copy of any publication from the public portal for the purpose of private study or research.

- You may not further distribute the material or use it for any profit-making activity or commercial gain

If the publication is distributed under the terms of Article $25 \mathrm{fa}$ of the Dutch Copyright Act, indicated by the "Taverne" license above, 


\title{
Methods of Monitoring Cell Fate and Tissue Growth in Three-Dimensional Scaffold-Based Strategies for In Vitro Tissue Engineering
}

\author{
Anne M. Leferink, $\mathrm{PhD}^{1-3}$ Clemens A. van Blitterswijk, $\mathrm{PhD}{ }^{1,2}$ and Lorenzo Moroni, $\mathrm{PhD}^{1,2}$
}

In the field of tissue engineering, there is a need for methods that allow assessing the performance of tissueengineered constructs noninvasively in vitro and in vivo. To date, histological analysis is the golden standard to retrieve information on tissue growth, cellular distribution, and cell fate on tissue-engineered constructs after in vitro cell culture or on explanted specimens after in vivo applications. Yet, many advances have been made to optimize imaging techniques for monitoring tissue-engineered constructs with a sub-mm or $\mu \mathrm{m}$ resolution. Many imaging modalities have first been developed for clinical applications, in which a high penetration depth has been often more important than lateral resolution. In this study, we have reviewed the current state of the art in several imaging approaches that have shown to be promising in monitoring cell fate and tissue growth upon in vitro culture. Depending on the aimed tissue type and scaffold properties, some imaging methods are more applicable than others. Optical methods are mostly suited for transparent materials such as hydrogels, whereas magnetic resonance-based methods are mostly applied to obtain contrast between hard and soft tissues regardless of their transparency. Overall, this review shows that the field of imaging in scaffold-based tissue engineering is developing at a fast pace and has the potential to overcome the limitations of destructive endpoint analysis.

\section{Introduction}

$\mathbf{T}$ HE FIELD OF tissue engineering has been quickly growing for more than two decades. Numerous approaches for several applications have been under investigation and various challenges related to cell fate control, biocompatibility, and structural integrity of tissue-engineered constructs among others have been overcome. Currently, the quality of engineered tissue constructs is mostly assessed by conventional destructive methods such as histological analysis. ${ }^{1}$ However, this approach results in the assessment of cell activity and produced extracellular matrix (ECM) only at the end of cultures so that the culture period is still treated as a black box with limited possibilities to steer culture conditions in a rational manner.

Data obtained by real-time nondestructive methods often lack spatiotemporal information since these methods treat a tissue-engineered construct as a bulk material. ${ }^{2}$ Therefore, there is a growing interest in novel methods to be able to nondestructively, and ideally noninvasively, assess the performance of tissue-engineered constructs with a sufficient spatiotemporal resolution upon in vitro culture before im- plantation. ${ }^{3-5}$ By gaining more insights in cell fate and tissue growth during culture, higher efficiencies and faster procedures could be realized.

Tissue engineering approaches can be generally divided into two main classes, which consist of (1) cell-based approaches without the presence of any supporting material and (2) combinatorial approaches in which cells are introduced into biological or synthetic materials supporting proliferation or differentiation. In this review, we will outline current methodologies and challenges with respect to the characterization of this second class of combinatorial scaffold-based tissue engineering approaches. We will specifically focus on the applicability of imaging modalities to assess cell fate when cultured on scaffolds fabricated of solid materials for musculoskeletal tissue engineering approaches.

Recent reviews have been published on studies that have addressed the importance of nondestructive assessment of tissue constructs' quality by the application of imaging methods. ${ }^{6-10}$ However, the majority of these studies focus on scaffolds' geometry characterization before cell seeding in vitro or cell labeling and tracking after implantation

\footnotetext{
${ }^{1}$ Department of Tissue Regeneration, and ${ }^{3}$ BIOS/Lab-on-a-chip Group, MIRA Institute, University of Twente, Enschede, The Netherlands.

${ }^{2}$ Department of Complex Tissue Regeneration, Maastricht University, Maastricht, The Netherlands.
} 
in vivo. ${ }^{11}$ These in vitro and in vivo studies unfortunately do not all address other challenges faced when monitoring the scaffolds combined with cells in vitro.

The limited penetration depth for most microscopy techniques forms one of these major constraints. ${ }^{12}$ Conventional imaging techniques such as laser confocal microscopy or transillumination microscopy require the use of thin samples or suffer from spatial resolution, respectively, to study the cell-scaffold interaction, cellular distribution, and proliferation during scaffold population. ${ }^{12}$ So, the applicability of imaging modalities highly depends on the type of scaffold used and the biological components to be detected.

First, we will highlight some of the most used scaffold materials and fabrication methods and their limitations with respect to monitoring tissue growth, cell fate, and/or cell metabolism. Second, we will summarize conventional methods for tissue growth, cell fate, and cell metabolism assessment. Subsequently, imaging modalities, which are potential candidates to monitor the previously mentioned parameters, will be introduced.

\section{Scaffold-Based Tissue Engineering}

In scaffold-based tissue engineering, biological or synthetic materials are processed into three-dimensional (3D) constructs or particles that enable cell growth within the final structure. Depending on the nature of these materials, the constructs can be hydrogel based or comprise solids. Hydrogels mostly retain optical transparency, whereas many solid scaffolding materials can be autofluorescent, semitransparent, or opaque. These differences in optical properties obviously result in different challenges faced when monitoring cell fate, tissue growth, and cell metabolism by imaging modalities. In this study, we will shortly outline two classes of conventional scaffold materials, followed by scaffold fabrication methods that have shown their relevance in musculoskeletal tissue engineering.

\section{Scaffold materials}

Natural materials. In many tissue engineering approaches, natural materials such as bioceramics, bioglasses, and biopolymers have gained interest because of their chemical properties, processability, and availability. ${ }^{13}$ Biological materials can be divided in several classes, namely materials retrieved from inorganic materials or plants, from animal species (xenogeneic), or from allogeneic and autologous sources. Generally, when materials for scaffolds are retrieved from inorganic substances or a plant, a certain component is isolated and purified, after which, in most cases, the macrostructure will be lost.

Materials of interest vary from relatively brittle and stiff materials such as ceramics to relatively soft materials such as biopolymers, which can be processed into hydrogels. Some commonly used bioceramics such as hydroxyapatites find their potential in bone tissue engineering because of their known osteoconductive and/or osteoinductive properties. ${ }^{14-17}$ Biopolymers, which can be divided in polysaccharides, proteins, and polyesters, are also of interest in several tissue engineering approaches. ${ }^{18}$ For example, in cartilage tissue engineering research, hydrogels comprising collagen, alginate, hyaluronic acid, or chitosan, among others, are widely applied as ECM-mimetic materials. ${ }^{19-26}$
Furthermore, silk, marine shells, and corals have been used as sources for biological materials in several tissue engineering approaches. ${ }^{27-32}$ Bioceramics are crystalline and therefore opaque materials, whereas bioglasses and biopolymers are semicrystalline or fully amorphous, permitting a certain degree of transillumination.

Decellularized ECM scaffolds from xenogeneic, allogeneic, or autologous sources are opted as promising nonimmunogenic materials for several tissue engineering approaches since their composition mimics the native tissues to a great extent. ${ }^{33-36}$ However, it is well known that the structure of the native ECM may be modified or even disrupted in the decellularization process. $^{37,38}$ Therefore, in soft tissue engineering, these obtained ECM components are mostly processed as a hydrogel, ${ }^{39-42}$ which offers a matrix for cell encapsulation and permits cell fate monitoring by optical imaging modalities. In other works, some scaffold fabrication techniques such as electrospinning have been applied to regain cellinstructive structural elements of the native ECM after decellularization, which leads to the fabrication of nanofiber meshes mimicking the structure of native ECM. ${ }^{43-45}$

For musculoskeletal tissue engineering and especially bone tissue engineering, hard tissue replacements are favored, which will require sufficient mechanical stability and structural integrity to sustain the loading conditions in the implantation site. Therefore, combinatorial approaches of synthetic materials with decellularized ECM have been investigated to retain both the native tissue properties of the ECM components and the mechanical properties of the (synthetic) scaffold material. ${ }^{46-48}$ Several processes of decellularization and their tissue sources and applications are well reviewed elsewhere. $^{49-52}$

Synthetic materials and composites. Synthetic materials represent a large class of widely used materials in tissue engineering approaches. Upon material synthesis, mechanical properties, surface chemistry, and degradability can be tailored. Furthermore, synthetic materials are generally easily processed into scaffolds by various methods, which will be outlined in the next section. Synthetic polymers have received considerable attention and are widely studied in cartilage and bone tissue engineering. ${ }^{53}$ Natural polymers are often difficult to process and pathogenic risks may be involved with natural polymers retrieved from xenogeneic or allogeneic sources. Synthetic polymers exclude these drawbacks and exhibit tailorable, predictable, and reproducible physical, chemical, and degradation properties. ${ }^{54}$ Depending on several parameters such as the degree of branching, hydrophilicity, and molecular weight of the polymer, synthetic polymers can be processed both as hydrogels and as solid materials. Some well-known polymers used for hydrogel fabrication are poly(acrylic acid), poly(ethylene oxide) (PEO), poly(vinyl alcohol), and polypeptides. ${ }^{55}$ Examples of the most popular and most widely studied biodegradable synthetic polymers in bone tissue engineering are poly-L-(lactic acid) (PLA), poly(glycolic acid) (PGA), and their copolymers poly-(lactic-co-glycolic acid) (PLGA). ${ }^{53,56}$ Furthermore, other synthetic polymers have been investigated for cartilage and bone reconstruction such as poly-(ethylene glycol) (PEG)-based polymers, ${ }^{57,58}$ poly- $\varepsilon$-(caprolactone) (PCL) ${ }^{59}$ polycarbonates, ${ }^{60}$ polyfumarates, ${ }^{61}$ polyanhydrides, ${ }^{62}$ and poly-(ethylene oxide 
terephthalate)/poly-(butylene terephthalate) $(\mathrm{PEOT} / \mathrm{PBT})^{63}$ copolymers or blends thereof. ${ }^{64,65}$

Even though many polymer materials have been synthesized and investigated, to date, no single polymer can meet all the requirements set for scaffolds in cartilage and bone tissue engineering. ${ }^{64}$ All polymers have their own characteristics, benefits, and drawbacks. Composite materials often show improved characteristics compared with their individual components with a sufficient balance between strength and toughness. Taking into account the composition of native bone, in which both organic and inorganic components are found, makes composite materials a logical choice for bone tissue engineering scaffolds. ${ }^{53,66}$ Combinatorial approaches, in which synthetic materials are used together with biological materials, offer both a high degree of tailorability in mechanical properties and enhanced instructive properties due to their biological activity. ${ }^{67,68}$ These instructive properties can result in enhanced cell attachment, proliferation, and differentiation. ${ }^{18,48,69-73}$

Similar to decellularized matrices and biological materials, the optical properties of scaffolds made of synthetics are dependent on their crystallinity, autofluorescent properties, absorption coefficient, processed geometry or porosity, and scaffold dimensions.

\section{Scaffold fabrication methods}

In the past two decades, a library of scaffold fabrication methods for tissue engineering applications has been developed. For nearly all common scaffold-based applications, reviews on fabrication processes can be found. ${ }^{54,74}$ In a review from Weigel et al., several commonly used fabrication methods are outlined with examples of specific applications per method. ${ }^{75}$ In the following section, we will shortly introduce not only some well-known methods but also some recently developed scaffold fabrication methods and their implications in imaging methods. A resulting example from each method is given in Figure 1.

Phase separation methods. One of the earliest scaffold fabrication processes is based on phase separation principles (Fig. 1A). The methods and parameters in phase separation processes have been reviewed recently. ${ }^{76}$ Highly porous scaffolds obtained by phase separation techniques find their use in a broad range of applications from soft scaffolds to study vascularization to sponge-like constructs for cartilage regeneration and stiff scaffolds for bone tissue engineering. ${ }^{77-80}$ The porosities obtained by these fabrication methods vary per polymer type and concentration, but mostly range from $\sim 60 \%$ to $97.5 \%$. $^{76}$

The morphology of the obtained pores is often torturous, irregular, and the pores generally show a large pore size distribution up to 10 -fold within one construct. Generally, the pore sizes can range from submicrometer to a few hundred microns and are, besides the degree of interconnectivity, largely dependent on the applied chemicals and the process parameters. ${ }^{76}$ One specific benefit of phase separation methods is the possibility to create longitudinal pore shapes ${ }^{81}$ or to introduce pore size gradients within the scaffold. ${ }^{82}$

The transparency of the material used will be a major determinant in the applicability of optical imaging techniques. Yet, even with transparent materials, the torturous geometry of the pores introduces many interfaces in the optical path, which will inevitable result in enhanced scatter and diffraction. The high porosity, and therewith low bulk density of these constructs, is expected to complicate imaging by nonoptical methods. Specifically, methods in which contrast is based on the material's nature with a spatial resolution limited to several microns will
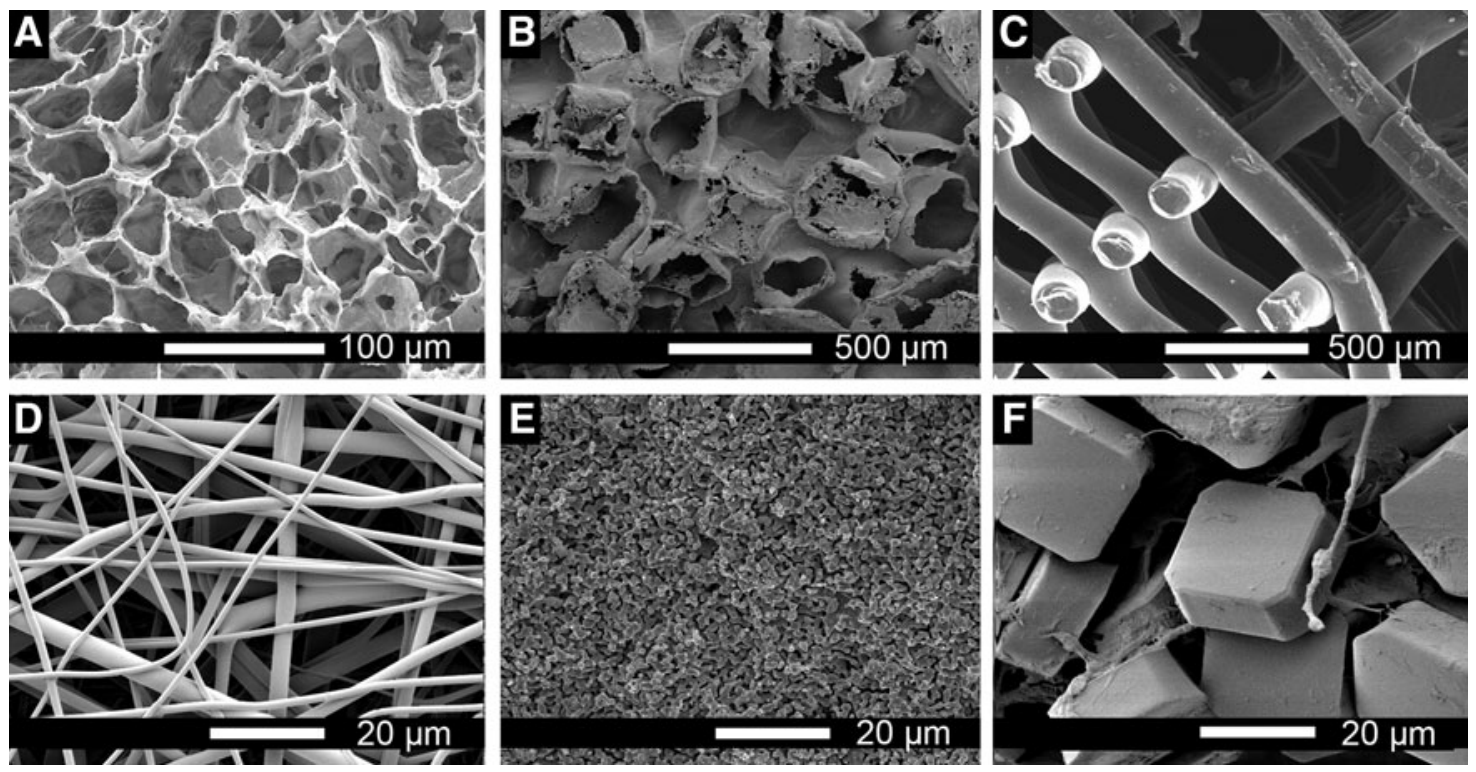

FIG. 1. Resulting scaffold structures from various fabrication methods. (A) Thermally induced phase separation method applied on a $7 \%$ solution of poly(caprolactone) in 1,4-dioxane. (B) Salt-leached scaffolds of poly-(lactic-co-glycolic acid). (C) Fused deposition-modeled scaffolds of PEOT/PBT. (D) Electrospun meshes of PEOT/PBT. (E) Sintered tricalcium phosphate discs. (F) SU-8 micro-objects assembled by hMSCs into porous aggregates. PEOT/PBT, poly-(ethylene oxide terephthalate)/poly-(butylene terephthalate). 
suffer from the limited thickness of the material layers that are separating the pores.

Particle leaching. Particle leaching methods result in 3D porous matrices, in which the pore sizes are controlled by the size of the particles (typically in the order of tens to hundreds of microns) and the porosity and interconnectivity are determined by the concentration of particles per scaffold volume (Fig. 1B). ${ }^{83-86}$ Particle-leached scaffolds are fabricated by casting a solution of a ceramic or polymer, for example, with solid particles. ${ }^{83,87}$ After the casted solution turned solid by evaporation of the solvent or by cooling down under the melting temperature, fully solid constructs are retrieved. Subsequently, the particles are leached out by immersing the full construct in a solvent for the particles, but a nonsolvent for the chosen polymer. This results in scaffolds with porosities in the range of $30 \%$ to $98 \% .^{88}$ The most commonly used particles are sugar or salt based because of their good solubility in water.

The types of scaffolds retrieved with this method are besides many other applications also widely applied in musculoskeletal tissue engineering, membrane-like scaffolds for urological purposes, and in in vitro vascularization research. ${ }^{89}$ The limitations in imaging these types of scaffolds are similar to those of scaffolds fabricated by phase separation methods. This similarity is caused by the comparable nature of the scaffold's geometry, introducing many thin layers per volume in highly porous scaffolds.

Additive manufacturing. Additive manufacturing techniques allow researchers to generate scaffolds with outer geometries based on computer-aided design (CAD). ${ }^{90-92}$ The field of additive manufacturing includes fused deposition modeling of thermoplastic materials, ${ }^{93-95} 3 \mathrm{D}$ printing of pastes or liquids, ${ }^{96}$ selective laser sintering (SLS), ${ }^{97-100}$ and stereolithography applied to photosensitive materials. ${ }^{101-104}$ Additive manufacturing techniques gained interest because of the capability to create scaffold geometries with welldefined parameters and high reproducibility (Fig. 1C). ${ }^{74}$ This results in scaffolds with porosities and pore size virtually ranging in the whole possible spectrum. Typically, manufactured scaffolds with porosities from $30 \%$ to $95 \%$ and with pore size ranging from tens of microns to millimeters have been reported. ${ }^{74}$ Another degree of freedom is enabled by the stepwise or layer-by-layer processing in additive manufacturing methods, which allows combining multiple materials into one construct.

Due to the often relatively large pores and the geometries introduced by these methods, many scaffolds only block the applicability of imaging methods to a certain extent, even if the materials are opaque. One can imagine that the regular structure of the construct enables observations through longitudinal pores. When transparent materials are used, the number of interfaces that optical light will have to cross is much lower than for scaffolds produced with phase separation or particle leaching methods. However, high resolution at greater imaging depths will still be limited, mainly due to the numerical aperture of the objectives that will be utilized.

Electrospinning. Electrospinning (ES) is a commonly used scaffold fabrication process to obtain nano- to microfiber meshes with high porosities, mimicking the collage- nous morphology of native ECM (Fig. 1D). ${ }^{105-107}$ The method is based upon charging a solution of a chosen material and subsequent extrusion through a capillary tip or needle. A jet is drawn from the needle toward a collector due to the presence of an electric field. Varying process parameters such as electric field strength distance between needle and collector, polymer concentration, and extrusion speed allow tuning of the fiber diameter and morphology. Fabricated scaffolds are typically meshes or membranes with porosities varying from $80 \%$ to $99 \%$, but with small pore sizes typically in the range of tens of nanometers till tens of micrometers. ${ }^{106}$ Since the ES process is mostly applied to fabricate sheets or discs with limited thicknesses (the majority between 200 and $500 \mu \mathrm{m}$ ), no major additional implications are expected to play a role in the applicability of imaging methods compared with other fabrication methods.

Sintering. Sintering is mainly applied for hard tissue engineering and is based on the heat treatment of a powder to make the nano- or microparticles partially fuse with each other. ${ }^{108-110}$ Sintered scaffolds cover a wide range of porosities from $5 \%$ to $80 \%$ with pore size ranging from tens of microns to submillimeter. ${ }^{88}$ Sintering is traditionally applied on ceramics, but it has also shown its potential for other materials such as metals, glasses, and certain polymers and composites (Fig. 1E).

Sintering can be applied locally with the use of lasers (SLS), which allows the fabrication of scaffolds with CAD geometries, as previously described in the section on rapid prototyping technologies. ${ }^{97}$ When sintering is applied to obtain a homogeneously dense construct of ceramic materials, imaging possibilities will be restricted to nonoptical material penetrating methods, such as microcomputed tomography (CT) or magnetic resonance imaging (MRI). When amorphous materials are utilized, optical methods could be applied. However, the multiple interfaces of material with culture medium upon in vitro culture will limit the achievable resolution and imaging depths due to scatter and diffraction.

Bottom-up approaches. Bottom-up approaches have been recently introduced to overcome hurdles faced with mm-sized 3D scaffolds caused by limited access of the scaffold for surface or bulk modification and functionalization, as well as for nutrient availability. These hurdles include inhomogeneous cell distribution, ${ }^{111}$ necrotic cores, ${ }^{112}$ a limited remodeling capacity, and a limited control of cell fate. In bottom-up approaches, materials and cells are first combined at the cellular level and allowed to form so-called building blocks before assembling into larger clinical relevant-sized constructs. The formation and secondary assembly of these building blocks can be both cell and material guided. Bottom-up designs have shown the potential to construct tissues with defined properties, including spatial and temporal control at a cellular level. ${ }^{113,114}$ The porosities and pore sizes are determined by the physical properties of the individual units and by the assembling properties and can in theory be ranging from $\sim 10 \%$ to $90 \%$ and from nanometers to hundreds of micrometers, respectively. With the freedom in modulating the sizes and shapes of the building blocks, the most optimal porosity and pore size per application can be easily fabricated. ${ }^{88}$ By creating micrometer-scaled building blocks from cells combined 
with biomaterials eventually comprising instructive capacities, complex tissues can be created and mechanisms of tissue development can be studied (Fig. 1F). ${ }^{115}$ When using monodispersed spheres, compaction will be limited, introducing a high interconnectivity. ${ }^{116}$

Bottom-up approaches based on gel-like materials allow the cells to reside in an ECM-mimicking matrix, retaining their rounded morphology. ${ }^{114,117}$ The use of hydrogels and engineered micro-objects has shown a high potential in injectable systems to reduce the invasiveness of surgical procedures in vivo and allow for controlled assembly to achieve complex tissues in vitro. The applicability of imaging methods to monitor cell fate and tissue growth in bottom-up engineered scaffolds is dependent on the optical properties of the materials used, the ratio of material versus tissue, and the density of the obtained 3D constructs.

\section{Imaging Modalities}

Imaging methods have gained growing interest over the past decades in the field of tissue engineering. The importance of noninvasive monitoring of cell and tissue behavior during culture, to be able to more rationally predict the success of the construct upon implantation, has been widely acknowledged. ${ }^{118}$

Conventional destructive quality assessment procedures such as histological analysis are still the golden standard, mostly because of their high spatial resolution and specificity. Yet, for these analyses, the engineered construct is sacrificed, which constrains the ability to instantly and accurately adapt culture conditions. Nondestructive technologies can overcome this inefficient and costly approach. Imaging-based nondestructive technologies enable real-time determination of parameters such as the cell number and distribution and the tissue type, content, and distribution. With these insights and understanding of culture conditions, immediate optimization of culture parameters could be carried out, which ultimately results in faster and more efficient procedures.

Generally, imaging modalities require changes in interactions of electromagnetic or mechanical energy among various substances to be able to retrieve contrast between these substances (Fig. 2). These changes in interactions include changes in energy due to absorption, refraction, or scattering. ${ }^{119,120}$ Parameters such as imaging depth, contrast, and spatial resolution achieved by a given imaging modality are largely based on the type and frequency of energy employed. The benefits and drawbacks of several imaging methods in the context of monitoring in vitro tissue-engineered constructs are described in the following sections and summarized in Table 1. Additionally, to obtain an impression of the capabilities of imaging methods, an overview with examples of obtained imaging results is given in Figure 3. In this study, we will outline some commonly used and some more promising imaging modalities for assessing in vitro tissue engineering constructs.

\section{Electron beam imaging}

The two most widely used electron beam-based imaging methods in tissue engineering are scanning electron microscopy (SEM) and transmission electron microscopy (TEM). SEM can provide high-resolution images up to a few nanometers, but has limitations with respect to penetration depth. ${ }^{121}$ In tissue engineering, SEM is mostly applied to assess scaffold quality after fabrication before cell culture or implantation and after culture or implantation. SEM is often referred to as destructive since conventional SEM requires dehydration and fixation of biological samples. ${ }^{9,122}$ However, there are SEM devices that have an environmental (ESEM) modality such as cryo-SEM, in which hydrated unfixed tissues can be studied. $^{121,123-125}$ In a study of Doyle et al., cryo-SEM was applied to study the morphology of colonies of fibroblasts on PLA. ${ }^{126}$ Yan et al. imaged cell growth of mouse osteoblast cells on plasma-treated PCL nanofibers in wet mode SEM. ${ }^{127}$ This method can not only be applied on large mm-sized constructs but also ESEM will only reveal information from the exterior surface of the construct.

Despite the benefits ESEM can offer over conventional high-vacuum SEM, it is not extensively applied in the field of tissue engineering, whereas it is a commonly used imaging method in food industry and plant sciences. TEM requires sample fixation and processing into thin sections and is therefore considered a destructive endpoint imaging method. ${ }^{128}$ Therefore, TEM has in our view no potential in noninvasive monitoring of tissue growth or cell fate in 3D constructs.

\section{Nuclear imaging}

Nuclear-based imaging techniques have shown potential in many in vivo applications such as visualization of lymphatic and vascular systems. ${ }^{129}$ For in vitro applications, however, to date, nuclear-based methods are not yet commonly applied. The lateral resolution of nuclear imaging modalities is limited since most available devices are mainly optimized for human-scale use with a resolution of $1-2 \mathrm{~mm} .{ }^{130}$ To be able to achieve contrast in nuclear-based imaging methods
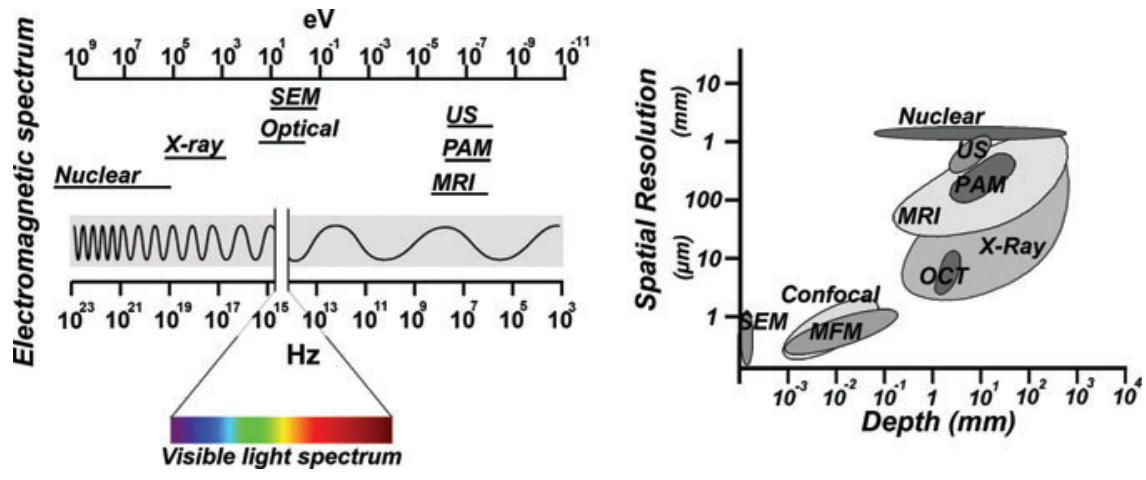

FIG. 2. The electromagnetic properties of various imaging modalities (left). Spatial resolutions and imaging depths obtained by conventional imaging methods applied on tissue samples (right). Color images available online at www.liebertpub.com/teb 
Table 1. Characteristics of Methods in Imaging Tissue Constructs in Vitro

\begin{tabular}{|c|c|c|c|c|c|c|}
\hline Class & Mode & $\begin{array}{l}\text { Living } \\
\text { tissue }\end{array}$ & $\begin{array}{l}\text { Opaque } \\
\text { scaffold }\end{array}$ & $\begin{array}{l}\text { Lateral } \\
\text { resolution }\end{array}$ & Depth & Comments \\
\hline Electron beam & High vacuum & - & ++ & ++ & -- & $\begin{array}{l}\text { Sample preparation required, only surface } \\
\text { of sample can be observed }\end{array}$ \\
\hline Electron beam & Wet mode SEM & \pm & ++ & \pm & -- & Only surface of sample can be observed \\
\hline Electron beam & Cryo-SEM & \pm & ++ & + & -- & Only surface of sample can be observed \\
\hline Electron beam & TEM & -- & ++ & ++ & -- & Sample preparation required, destructive \\
\hline Nuclear & PET & ++ & ++ & -- & ++ & $\begin{array}{l}\text { Radioactive agents required, optimized for } \\
\text { whole-body imaging, in combination with } \\
\text { CT anatomic coregistration of functional } \\
\text { information }\end{array}$ \\
\hline Nuclear & SPECT & ++ & ++ & - & ++ & $\begin{array}{l}\text { Radioactive agents required, optimized for } \\
\text { whole-body imaging, in combination with } \\
\text { CT anatomic coregistration of functional } \\
\text { information }\end{array}$ \\
\hline Optical & Stereomicro & + & \pm & \pm & - & $\begin{array}{l}\text { Reflection of light, only surface of (opaque) } \\
\text { sample can be observed }\end{array}$ \\
\hline Optical & Bright field & ++ & - & + & \pm & $\begin{array}{l}\text { Transillumination, only on thin and virtually } \\
\text { transparent constructs, low contrast on } \\
\text { biological materials }\end{array}$ \\
\hline Optical & Phase contrast & ++ & - & + & - & $\begin{array}{l}\text { Transillumination, only on thin and virtually } \\
\text { transparent constructs }\end{array}$ \\
\hline Optical & DIC & ++ & - & + & \pm & $\begin{array}{l}\text { Transillumination, only on thin and virtually } \\
\text { transparent constructs }\end{array}$ \\
\hline Optical & Fluorescence & ++ & - & ++ & \pm & $\begin{array}{l}\text { Various modalities available with a broad range } \\
\text { of imaging depths and resolutions. Application } \\
\text { of fluorescent labels is not always required }\end{array}$ \\
\hline Optical & MPM & ++ & - & ++ & + & $\begin{array}{l}\text { Deeper penetration depth than conventional } \\
\text { fluorescence microscopy }\end{array}$ \\
\hline Optical & SHG & ++ & \pm & ++ & + & $\begin{array}{l}\text { High photon densities required, moderate } \\
\text { phototoxicity, no fluorescent staining required }\end{array}$ \\
\hline Optical & Bioluminescence & ++ & \pm & \pm & ++ & Transgenic animals or cell lines required \\
\hline Optical & OCT & ++ & \pm & + & \pm & $\begin{array}{l}\text { Label-free, can be combined with e.g., Doppler } \\
\text { velocimetry, suited for highly scattering matter }\end{array}$ \\
\hline Optical & Raman & ++ & - & \pm & \pm & $\begin{array}{l}\text { Label-free, spectroscopic: image conversion } \\
\text { required }\end{array}$ \\
\hline Echo & US & ++ & ++ & - & + & $\begin{array}{l}\text { Dependent on sound transmission properties } \\
\text { of sample }\end{array}$ \\
\hline Light/sound & PAM or PAT & ++ & \pm & - & ++ & $\begin{array}{l}\text { Not suitable for imaging bony tissues } \\
\text { or air-filled matter }\end{array}$ \\
\hline X-ray & Micro-CT & \pm & ++ & \pm & ++ & Radiation applied \\
\hline Magnetic & MRI & ++ & ++ & + & ++ & Often contrast agents are required \\
\hline
\end{tabular}

The symbols indicate applicability and/or quality of the method in the given situation. These indications are based on the authors' interpretation of reported results.

_, not applicable/very low quality; -, limited applicable/low quality; \pm , somewhat applicable/reasonable quality; +, applicable/good quality; ++, very applicable/very good quality. CT, computed tomography; DIC, differential interference contrast; MPM, multiphoton microscopy; MRI, magnetic resonance imaging; OCT, optical coherence tomography; PAM, photoacoustic microscopy; PAT, photoacoustic tomography; PET, positron emission tomography; SEM, scanning electron microscopy; SHG, second harmonic generation; SPECT, single-photon emission computed tomography; TEM, transmission electron microscopy; US, ultrasound.

such as single-photon emission computed tomography (SPECT) and positron emission tomography (PET), radioactive agents are required.

Although PET and SPECT cannot yet provide single-cell resolution, which would be desirable in monitoring cell fate in tissue-engineered constructs, both methods could still be valuable tools enabling cell cluster localization and cell function in vivo and in vitro. For example, by labeling cells with radioactive tracer molecules such as fluorine-18radiolabeled fluorodeoxyglucose $\left({ }^{18} \mathrm{~F}\right.$-FDG) or fluorine-18radiolabeled 9-[4-fluoro-3-(hydroxymethyl)butyl]guanine $\left({ }^{18} \mathrm{~F}-\mathrm{FHBG}\right)$ for PET imaging, noninvasive cell tracking is aided (Fig. 3A). ${ }^{131,132} \mathrm{~A}$ drawback of ${ }^{18} \mathrm{~F}-\mathrm{FDG}$ is the high tracer elution rate from the cells, ${ }^{133}$ which makes this tracer mainly applicable for short-time monitoring. ${ }^{134}$ In addition, for SPECT, a library of tracers is developed, which can be targeted to specific cell surface receptors, metabolites, or genes. ${ }^{135-137}$ The addition of CT to PET or SPECT imaging has shown to allow precise anatomic coregistration of functional information with anatomy in small animals. ${ }^{138}$ Recently, micro-SPECT was developed and compared with micro-CT to image a whole-mouse skeleton; however, anatomical atlas-based segmentation and image processing were required to be able to reconstruct $3 \mathrm{D}$ models of the detected skeleton (Fig. 3B). ${ }^{139}$ Furthermore, applying tools such as pinhole collimators to improve SPECT resolution has the 


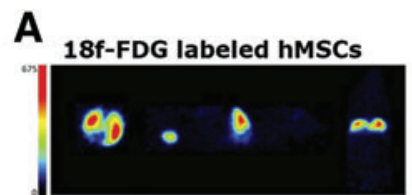

18f-FDG labeled MAPCs

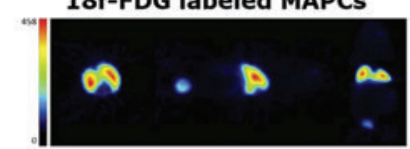

D
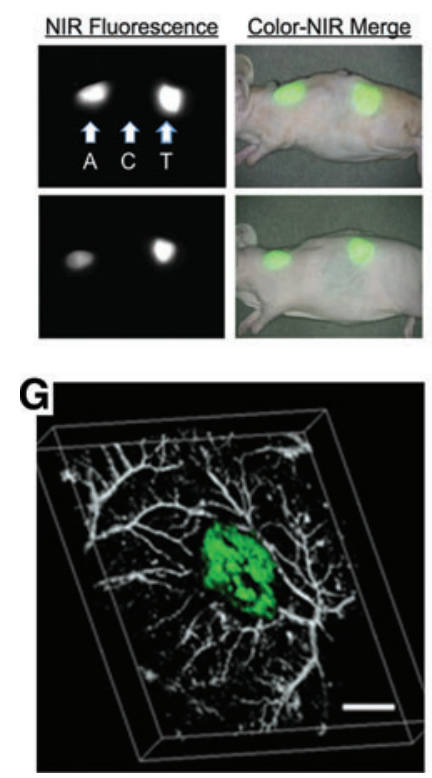

B
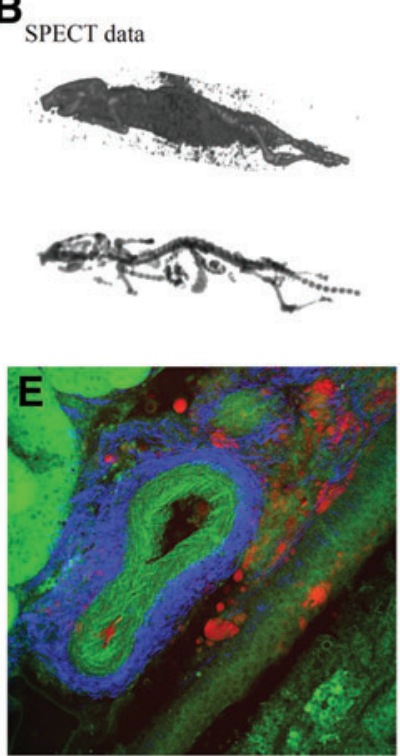

H

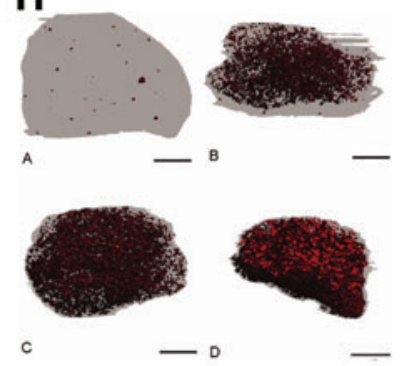

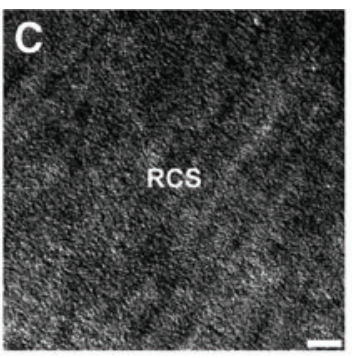
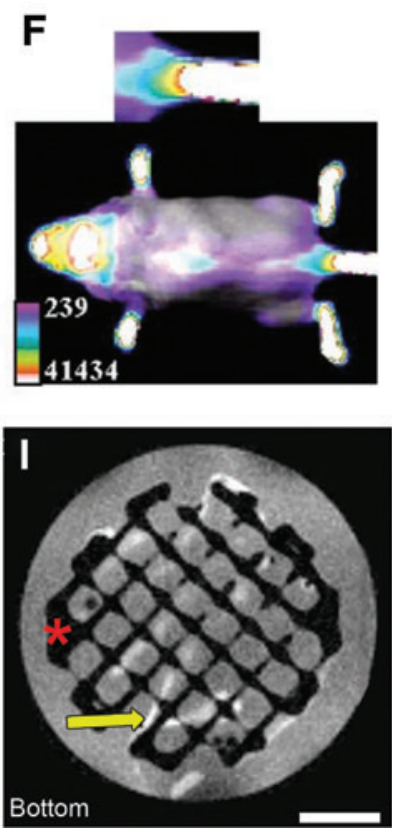

FIG. 3. Examples of results of various imaging methods applied in vitro and in vivo for cell tracking or tissue or scaffold characterization. (A) Nuclear-based imaging methods such as positron emission tomography can provide functional information on cells by the uptake of specifically labeled radioactive agents. This research was originally published in $J N M^{131}$ (C) by the Society of Nuclear Medicine and Molecular Imaging, Inc. (B) SPECT enables the imaging of hard tissue materials in small animal models. By segmentation and image reconstruction, 3D anatomical models can be obtained. ${ }^{139}(\mathbf{C})$ Differential interference contrast microscopy of in vitro cultured corneal fibroblasts on a disorganized reconstituted collagen substrate to study collagen remodeling by fibroblasts. ${ }^{111}$ (D) Near-infrared fluorescence microscopy to study scaffold degradation in vivo. ${ }^{153}(\mathbf{E})$ A multimodal image of a blood vessel in kidney tissue combining second harmonic generation (blue) with two-photon excitation fluorescence (green) and coherent anti-Stokes Raman scattering (red). Image courtesy of Eric Potma, University of California, Irvine. (F) Bioluminescence of luciferase expressed in hypertrophic cartilage and trabecular bone in a transgenic mouse model. (G) Imaging of a lacZ-marked tumor and its associated microvasculature by dual-wavelength acoustic-resolution photoacoustic microscopy in vivo. ${ }^{213}(\mathbf{H})$ Typical micro-CT images of osteoblasts after 21 days of culture on scaffolds consisting of hydroxyapatite and collagen in various ratios. ${ }^{225}$ (I) Human bone marrow stromal cells and newly formed extracellular matrix (arrow, white) in an opaque 3D additive manufactured scaffold (asterisk, black) imaged by magnetic resonance imaging. ${ }^{239}$ For all images, reprint permission was granted through a singleuse license (A, C-F, and $\mathbf{H})$ or through the creative commons (CC-BY) license (B, $\mathbf{G}$, and $\mathbf{I})$. 3D, three-dimensional; SPECT, single-photon emission computed tomography. Color images available online at www.liebertpub.com/teb

consequence that longer scanning times are required due to reduced photon sensitivity. ${ }^{138}$ Overall, PET and SPECT have high potential in clinics to add functional information on to anatomical structures imaged by other imaging modalities. Yet, the applicability of nuclear-based imaging methods on in vitro tissue-engineered constructs with a sub-mm scale resolution is to date still limited.

\section{Optical imaging}

Optical imaging is based on systems that measure the interaction of light ( $\sim 10$ up to $400 \mathrm{~nm}$ for ultraviolet, $400 \mathrm{~nm}$ up to $710 \mathrm{~nm}$ for visible light, and $710 \mathrm{~nm}$ to $1 \mathrm{~mm}$ for infrared light) with matter. These interactions can show differences in scatter, absorption, or luminescence, which depending on the imaging modality, can be optically visible or can be displayed after computing retrieved spectra into images.

Epi- and transillumination microscopy. In epi- and transillumination microscopy, visible light is projected onto a specimen and contrast or colors are dependent on absorption and reflection, scatter, and breaking of the light. Epiillumination modalities such as stereomicroscopy are applied on opaque specimens, from which reflected light is captured revealing information from the surface of the specimens only. Commonly used transillumination microscopy-based imaging 
modalities are bright-field microscopy, phase-contrast microscopy, ${ }^{140}$ and differential interference contrast (DIC) (Fig. 3C) ${ }^{141}$ microscopy, for which the applicability is restricted to imaging two-dimensionally (2D) and in 3D to thin $(<300 \mu \mathrm{m})$ and virtually transparent constructs. ${ }^{9}$

Bright-field microscopy renders most detail of living cells invisible since there are no large differences in absorption by the structures inside cells. Phase-contrast microscopy is based on differences in refraction, which lead to a phase delay in some of the light causing contrast in the images. DIC imaging allows detailed microscopic examination of the matrix texture and cell orientation in the plane of the construct $^{141}$ and can be applied to study dynamics in living cells since this method is noninvasive and continuous. ${ }^{142}$ For several types of rapid prototyped scaffolds with longitudinal pores cultured with cells in vitro, bright-field microscopy can still be applied to gain some insight in tissue growth in the early phase. However, when the formed tissue becomes denser, complete absorption of the light will inhibit further assessment with transillumination-based methods.

Fluorescence microscopy. Optical fluorescent imaging has developed into an important tool in biomedical research both in vitro and in vivo. Fluorescence microscopy allows for noninvasive cell and tissue monitoring, in which contrast is offered by differences in autofluorescent properties of tissue constructs due to endogenous fluorophores present in all tissues, ${ }^{143-145}$ endocytosis or transfection of fluorescent probes, ${ }^{146}$ or targeted fluorescent exogenous probes. ${ }^{147,148}$ Depending on the fluorescence modality applied (e.g., epifluorescence, confocal fluorescence, multiphoton fluorescence) and the excitation wavelengths utilized, imaging depths between submicron up to whole-animal imaging in the $\mathrm{cm}$ scale can be achieved. ${ }^{149,150}$ The majority of studies on cell fate, in which fluorescence microscopy is applied in $3 \mathrm{D}$, are focused on in vivo cancer metastasis, cell homing, and cell differentiation. ${ }^{151}$

Martin et al. showed that combining bright-field microscopy with fluorescent microscopy on ex vivo slices of unstained bone scaffolds enables the quantification of formed bone matrix by autofluorescence detection. ${ }^{144}$ Cowles et al. applied near-infrared (NIR) optical imaging with a bonespecific NIR-targeted probe to noninvasively study mineralization of tissue-engineered bone constructs over time in vivo. ${ }^{152}$ By the application of NIR, imaging problems related to autofluorescence from the native tissue can be eliminated. ${ }^{138}$ In another study, NIR fluorescent imaging was applied to monitor scaffold degradation in vivo. ${ }^{153}$

For in vitro cell studies, de Mel et al. showed that biofunctionalized quantum dots have great potential for live monitoring of endothelial progenitor cells seeded in mmsized polymeric scaffolds and cultured in a pulsatile flow bioreactor for vascular tissue engineering applications. ${ }^{154}$ Although, whole-body imaging of mice was shown to be feasible, the spatial resolution with such imaging depths drastically decreased from submicron to $\mathrm{mm}$ scale, in which only clusters of cells were detectable. ${ }^{149,155}$ Recent studies have shown in vivo assessment of cell migration in living mice with a subcellular resolution. ${ }^{156,157}$ Although the applied methods are classified as noninvasive and label-free, the continuous expression of fluorescent proteins to monitor cellular migration over time with a subcellular resolution requires genetic modifications in the applied cell lines or animals. For more information on the current state of the art in live cell imaging in whole animals by the application of fluorescent proteins, one can refer to a review from Hoffman. ${ }^{158}$ Most conventional fluorescent microscopes found in tissue engineering laboratories have limited penetration depths of both the excitation and emission wavelengths when applied on dense tissues such as cartilage and bone and on opaque materials.

Multiphoton microscopy and second harmonic generation. Fluorescence microscopy has long been used for visualizing cells and angiogenesis in scaffolds as described earlier. However, due to strong light scattering, especially in the presence of blood, conventional fluorescence microscopy shows poor tissue penetration of several hundred micrometers. Multiphoton microscopy (MPM) has shown to partly overcome this limitation and allows imaging two to three times deeper into specimens and enables optical sectioning into stacks for 3D reconstruction. ${ }^{159,160}$ For MPM, some specialized optical effects can be applied to enable label-free imaging of cells within scaffolds without the requirement of sample preparation. ${ }^{12}$ Imaging with second harmonic generation (SHG) requires high photon densities and, to avoid tissue damage, short pulses of laser light, as provided by picosecond or femtosecond multiphoton lasers. ${ }^{142}$

Conventionally available multiphoton lasers generated light with wavelengths ranging from 700 to nearly $1000 \mathrm{~nm}$. The emission detection for SHG will be in the range of 350$500 \mathrm{~nm}$ when these lasers are applied. In biological specimens, SHG signals are obtained from proteins that contain a high amount of higher-order structures, for example, from alpha-helical structures, which are present in collagens and elastic fibers. ${ }^{161}$ Because of its high resolution and penetration depth, yet with only moderate phototoxicity, this technique holds strong promise for future developments in live cell and matrix research exploiting nonlinear molecular characteristics of molecules and tissues.

Sun et al. have applied a combinatorial modality of MPM with SHG imaging to investigate the nonlinear optical properties of five commercially available scaffold materials: a collagen composite scaffold, a bone graft matrix strip (collagraft), an open-cell PLA scaffold, a PGA scaffold, and a nylon mesh. ${ }^{162}$ They showed that MPM is effective in providing spectrally resolved morphological information of the materials and hypothesized (yet did not show) that this method can be used to study cell-matrix interactions when cells are cultured on these scaffolds. In other studies, MPM was applied on tissue-engineered constructs and was combined with SHG imaging to noninvasively retrieve insights on the interaction between scaffolds and tissues or between scaffolds and cells in vitro and in vivo. ${ }^{118,163,164}$ For example, in the study of Lee et al., ECM formation on PGA electrospun scaffolds was followed and showed to initially align along the scaffold fibers, while after inducing chondrogenesis for several weeks, scaffold reorganization was observed. ${ }^{118}$

Pena et al. have also shown scaffold remodeling during culture, in this case, in collagen matrices seeded with fibroblasts. $^{164}$ Furthermore, combining SHG with MPM showed that among other structural parameters, the molecular orientation of the sample and the overall beta sheet content could be detected. ${ }^{145,165}$ Overall, combinatorial 
imaging modalities based on MPM and SHG provide information about materials present in tissue-engineered constructs, ECM components such as collagens, and cells simultaneously in separate channels. ${ }^{145,166}$ This allows for adequate (automated) image analysis of specific (labeled) components per channel. Ultimately, this enables novel approaches to directly modify culture parameters to induce or prevent certain cell and tissue fate-related processes.

Bioluminescence. Bioluminescence (BLI) uses light emission produced through enzymatic catalysis of, for example, luciferin by a luciferase enzyme. The principle has proven useful to monitor gene expression and cellular activities both in vitro and in small animal models in vivo. ${ }^{167-169}$ Several studies have shown the correlation between luciferase activity and the number of cells within tissues in vivo or scaffolds in vitro. ${ }^{170-173}$ Logeart-Avramoglou et al. have shown the quantification and characterization of luminescence from live cells and cell lysates after culture on polymeric translucent soft hydrogels and on opaque hard ceramics. $^{174}$ Olivo et al. reported a further correlation between luciferase activity, the number of cells, and bone formation in vivo. ${ }^{175}$ In another study, osteogenesis was assessed by monitoring gene expression-dependent BLI by coupling of luciferase reporters to the promoter of osteocalcin. ${ }^{172,176-178}$ Because of its high sensitivity, BLI technology has recently proven its usefulness in tracking stem cells on material scaffolds transplanted in live animals for tissue engineering purposes. ${ }^{178}$ One of the limitations of BLI is the limited resolution, which can range from tens of microns to millimeters. Furthermore, to the best of our knowledge, the current technology to image BLI does not allow for retrieving 3D imaging stacks of tissues and tissue constructs, thereby limiting the reconstruction modalities of $3 \mathrm{D}$ tissue development.

Optical coherence tomography. Optical coherence tomography (OCT) was first introduced by Huang et al. for the assessment of biological tissues. ${ }^{179}$ OCT has been used for label-free imaging of tissue/scaffold constructs at a relatively high resolution in the submicron range. ${ }^{9}$ Depending on the type of scaffold, it can be rather difficult to distinguish between the tissue and the scaffold when their refractive indices are similar. ${ }^{180,181}$ A light beam from a broad bandwidth light source is focused into a sample and the time that the light takes to return from the specimen to the detector is measured. This echo timeof-flight information enables the determination of the depth in the sample from where the light was scattered. ${ }^{120,179,182}$

OCT is applied in the field of tissue engineering to characterize the architecture of scaffolds, including porosity, pore distribution, and interconnectivity before cell culture. ${ }^{183}$ In deep tissue imaging, OCT is one of the most used optical imaging modalities for its high spatial resolution of $<15 \mu \mathrm{m}$ in scattering matter at depths up to $2 \mathrm{~mm}$. $^{184,185}$ Wang et al. applied OCT to assess scaffold-assisted wound healing in mice and compared their results with conventional H\&E staining. ${ }^{186}$ Tissue development in vitro was monitored with OCT by detecting an increase in backscattered light over time. ${ }^{187}$ In in vitro tissue engineering, OCT combined with Doppler velocimetry has been applied for characterization of flow in engineered tissues, such as artificial blood vessels, by increasing the obtained contrast compared with conventional OCT. ${ }^{188,189}$
In another study of Liang et al., three other combinatorial modalities have been introduced and evaluated for tissue engineering applications, namely OCT and multiphoton microscopy (OCM/MPM), optical coherence elastography (OCE), and spectroscopic OCT (SOCT). ${ }^{181}$ OCM/MPM enables imaging at greater depths in highly scattering tissues by combining the spatial optical sectioning capabilities of confocal microscopy with coherence gating and rejection of multiply scattered photons within one modality, resulting in high sensitivity and high contrast. ${ }^{181}$ This integrated system allows to obtain microstructural and functional properties of engineered tissues simultaneously and to display the data within one representation.

OCE reveals information on the biomechanical properties of tissues by applying mechanical stimulation to the material with simultaneous OCT detection. Dependent on the optical properties of the tissues, the main features of OCE can include millimeters of penetration depth and spatial resolution in the micron scale. SOCT is based on spectral analysis and intensity analysis of backscattered light from tissues. Similar to OCM, OCE, and conventional OCT, SOCT can obtain spatial resolutions in the micron scale. ${ }^{190}$ In conventional OCT, no exogenous fluorophores are required since OCT relies on variations in indices of refraction and optical scattering for image contrast. ${ }^{185}$ Therefore, OCT can be considered a noninvasive, label-free imaging modality, enabling cellular imaging within living specimens over time without loss of viability. ${ }^{191}$

Raman microspectroscopy. Raman microspectroscopy is a label-free spectroscopic technique, which does not require special sample preparation and can be used for noninvasive characterization of cell and tissue biochemistry. ${ }^{192,193}$ Careful selection of suitable laser wavelengths and laser intensity can eliminate cell damage, allowing for the study of cells without inadvertently changing their phenotype or behavior caused by photo damage. ${ }^{194-196}$ Raman spectral studies have been performed for structural analysis of ECM components such as collagen ${ }^{197}$ and proteoglycans. ${ }^{192,198}$ Raman peaks at distinct wavelengths exist, for example, for different types of carboncarbon bonds, amide, carboxyl, sulfhydryl, and phenol groups. ${ }^{120}$

In some relatively complex samples, Raman peaks could be characterized by entire molecules, such as carotenoids, glucose, and hydroxyapatite. ${ }^{120}$ Spectral information retrieved by scanning specimens over a certain area, optionally confocal, can be computed and displayed as 3D cluster images. ${ }^{199}$ Raman spectroscopy and Raman spectroscopy-based imaging have been successfully applied in several tissue engineering applications, for example, by monitoring chondrocyte behavior on bioactive scaffolds. ${ }^{200}$ Boyd et al. have utilized a benchtop macro-Raman spectrometer with high-throughput screening capability to examine spectral differences between well-characterized cell lines (two types of osteosarcoma cells, human dermal fibroblasts and human embryonic lung epithelial cells) and the effects of cellular death. ${ }^{201}$

\section{Ultrasound}

Ultrasound (US)-based imaging is in principal similar to OCT except that acoustic waves are used instead of NIR light. ${ }^{182}$ Compared with OCT, clinical US has a lower resolution, but higher penetration depth. Although US imaging is 
widely applied in the clinics, not much research has been reported on applying US methods on in vitro cultured scaffolds. US-based monitoring methods have, similarly to X-raybased micro-CT, OCT, and MRI, already been applied to nondestructively assess scaffold properties during and after fabrication. ${ }^{202,203}$

Mather et al. applied ultrasonic pulse-echo reflectometry to monitor changes in acoustic impedance of poly-(D,Llactic acid)-based scaffolds during supercritical scaffold fabrication. ${ }^{202} \mathrm{Kim}$ et al. introduced US elasticity imaging on tissue-engineered constructs to monitor scaffold degradation in vitro and in vivo with an axial and lateral resolution of $\sim 250$ and $500 \mu \mathrm{m}$, respectively. ${ }^{203}$ Yet, both these methods did not provide sufficient spatiotemporal information on the scaffold structure to be able to draw conclusions on tissue development throughout a 3D construct.

Rice et al. opted to use US to monitor cartilaginous matrix development in chondrocyte-seeded PEG hydrogels in vitro. ${ }^{204}$ Kreitz et al. have also evaluated the potential of US for quantitative in vitro monitoring of tissue development in a hydrogel-based 3D tissue-engineered construct. They showed a correlation between the gray-scale values of the obtained images with hydroxyproline content, which is a marker of collagen formation. ${ }^{205}$

In a study of Fite et al., US backscatter microscopy (UBM) was combined with time-resolved fluorescence to follow the progression of tissue maturation along the chondrogenic lineage by monitoring collagen type-2 production and by detecting changes in mechanical properties of PLGA-based constructs upon in vitro culture. ${ }^{206}$ UBM can provide structural information, respectively, with an axial and lateral resolution of $\sim 30$ and $65 \mu \mathrm{m}$ that can be correlated with tissue microstructure and construct stiffness, which can be a measure for the functionality of cartilage and bone-like tissue constructs. ${ }^{206}$ Overall, the applicability of US-based imaging methods to monitor tissue growth in mm-sized tissueengineered constructs highly depends on the aimed resolution and imaging depth, the targeted tissue type, and the sound transmission properties of these tissues and scaffold materials.

\section{Photoacoustic tomography and photoacoustic microscopy}

Photoacoustic tomography (PAT) is a relatively novel, but fast developing, clinically applied noninvasive and nonionizing method to monitor tissues in vivo and to detect, for example, blood oxygenation in situ. ${ }^{207-210}$ The method is based on the collection of ultrasonic waves resulting from heat expansion of tissues after absorption of laser irradiation within those tissues. ${ }^{211}$ Large imaging depths up to $\sim 7 \mathrm{~cm}$ can be achieved since the light only has to travel in one direction and will result in a sound wave upon absorption. ${ }^{212}$ In PAT and photoacoustic microscopy (PAM), the spatial resolution correlates with the imaging depth and depends on the application, yet a high depth-to-resolution ratio is maintained. ${ }^{213}$

Recently, a lateral resolution of $5 \mu \mathrm{m}$ with an imaging depth of $1 \mathrm{~mm}$ was obtained in highly scattering soft tissue. ${ }^{214}$ By modulating the US detection frequency after laser irradiation, PAT enables high-resolution imaging of biological structures with strong optical absorption contrasts. ${ }^{215}$ Although PAT and PAM are promising imaging methods for in vivo applications, to date, just a few researchers have investigated the potential of these methods for the field of tissue engineering. ${ }^{130}$ Recently, PAM has been applied to retrieve structural information on tissue engineering constructs in vitro ${ }^{216,217}$ and in vivo. ${ }^{122,214}$

Cai et al. incorporated carbon nanotubes in PLGA scaffolds to be able to obtain detectable contrast between the polymeric scaffold and surrounding tissue. ${ }^{216}$ Other approaches have introduced NIR fluorescent proteins in vivo to enable multicontrast next to already present endogenous contrast agents such as hemoglobin. ${ }^{211}$ Such contrast agents could also be applied to cells in vitro in tissue-engineered constructs. To be able to extract more information from tissue-engineered constructs, multimodal imaging techniques can be applied. PAM could, for example, be combined with US-based imaging as was already done in vivo. ${ }^{218}$

PAM has some limitations when imaging bony or airfilled tissues caused by limited transparency and the absence of a US wave transporting medium. ${ }^{214}$ Despite these two major limitations, we still consider PAT and PAM to be promising in analyzing biomaterial-tissue interactions in soft tissue engineering applications in a completely noninvasive and nonionizing manner.

\section{$X$-ray-based micro-CT}

Previously, X-rays were clinically applied as a fast diagnostic tool to obtain direct $3 \mathrm{D}$ whole-body projections on 2D photosensitive films. Currently, X-ray imaging combined with CT can be applied in scanning mode at distinct focal planes and with varying projection directions, enabling $3 \mathrm{D}$ reconstruction of the information. ${ }^{119,219,220}$ Depending on the spot size of the generated X-ray, the beam properties, and mostly the detector properties, nanometer scale resolution has been achieved. ${ }^{220}$

One of these CT modalities is micro-CT, which enables tissue engineers and material scientists to evaluate the morphological structures of their dry materials and fabricated scaffolds nondestructively with high resolution and accuracy. $^{221-223}$ However, when polymeric scaffolds are immersed in physiological fluids in vitro, or embedded in vivo, wherein fluids perfuse through the scaffolds, the contrast of micro-CT images has shown to be poor. ${ }^{216}$

Similar to MRI, micro-CT is also capable of distinguishing soft tissue material from harder mineralized tissues. $^{216,224}$ However, instead of contrast resulting from changes in proton dynamics, X-ray contrast is the result from differences in absorption, refraction, and/or scattering properties of the materials. Bone, fibrous tissue, and ceramic scaffolds present different coefficients of X-ray absorption, therefore their 3D structures can be separated and corresponding quantitative data such as bone volume, thickness, growth, destruction, remodeling, and changes in bone density can be obtained. ${ }^{22,225}$ However, contrast between distinct types of soft tissue with similar X-ray attenuation is limited $^{226}$ and requires high cell densities. ${ }^{24}$

One approach to improve contrast between various soft tissues is by the application of contrast agents. ${ }^{11}$ Tissue engineering studies that do not assess mineralization often require those toxic contrast agents or sample processing before imaging. Unfortunately, most stained scaffolds are no longer usable for culture due to high toxicity of the applied contrast agents. Another approach to improve contrast is by combining micro- 
CT with, for example, X-ray phase contrast. When these contrastrelated challenges can be overcome, monitoring of soft tissues and live cells during scaffold culture can be a major future application. ${ }^{6,227,228}$ Zhu et al. have shown the application of X-ray diffraction-enhanced imaging (DEI) on the characterization of rapid prototyped scaffold geometry, chitosan scaffold structure, and on muscle tissue morphology. ${ }^{228}$ With the latter, they showed the outstanding capacity of DEI to better image low-contrast soft tissues compared with both radiography and in-line phase-contrast imaging.

\section{Magnetic resonance imaging}

Applications of MRI are often described when methods for $3 \mathrm{D}$ noninvasive imaging of nontransparent biological materials in the $\mathrm{mm}$ scale with relatively high resolution are reviewed. $^{4,119,229}$ MRI can be applied either label-free or with targeted magnetic beads, for example, to be able to track or localize specific components or cells. ${ }^{230-232}$ Contrast in MRI images is based on proton densities and differences in the spin phase and relaxation time of these protons, among others, due to variations in tissue hydration or water/lipid ratios. ${ }^{233}$

MRI has shown to be a promising imaging modality for the assessment of musculoskeletal tissue-engineered constructs. ${ }^{7,234-239}$ In a study of Washburn et al., for instance, an inverse relationship between MR relaxation times and mineral concentration was found after culturing osteoblasts on poly-(ethyl methacrylate) scaffolds. ${ }^{240}$ Chesnick et al. showed that similar collagen mineralization results in cartilage tissue engineering. ${ }^{241}$ Other studies have shown a correlation between collagen orientation and $T_{2}$ relaxation times in articular cartilage ${ }^{242,243}$ and in tendons. ${ }^{244}$

Recently, advances have been made in the realization of MRI-compatible bioreactors to be able to assess cell fate and tissue growth longitudinally. ${ }^{245,246}$ Implementation of contrast agents in MRI enables cell tracking both in vitro and in vivo. ${ }^{232,247-250}$ Immobilization of contrast agents on nanoparticles is required for cell labeling through endocytosis. ${ }^{251,252}$ Upon endocytosis, accumulation of the agent leads to a darker or brighter signal, which will either reduce or increase the contrast between the labeled cells and the scaffolds, depending on the type of contrast agent used. ${ }^{253}$

Although MRI seems to be very promising in noninvasive tissue construct quality assessment, this technology has not yet become part of standard laboratory equipment. ${ }^{254}$ To increase the signal-to-noise ratio in a voxel, and consequently increase the spatial resolution, the use of high-field MRI and long scanning times are required. Devices capable of applying sufficient magnetic field strengths for microMRI are expensive and not yet developed to fit in standard tissue engineering laboratories. ${ }^{255,256}$

\section{Discussion and Future Outlook}

The need for novel approaches to monitor the cell and tissue-related parameters that play a major role in the success and quality of tissue-engineered constructs is well acknowledged. This monitoring is not only pivotal for the assessment of the engineered construct before implantation but can also aid in the optimization of the culture conditions. By gaining real-time insights in cell and tissue fate, direct interventions could be foreseen, which would increase the efficiency and decrease the costs of the chosen tissue engi- neering approach. These insights are expected to be of even greater value when spatiotemporal information is revealed.

In the past few decades, many scientists have put efforts in developing and optimizing noninvasive methods to assess tissue growth, cell fate, and scaffold integrity in vivo and in vitro. Despite all these advances reviewed here, the most applied method for the evaluation of the performance of a tissue-engineered construct still remains destructive histological analysis. One of the main reasons for this being that the golden standard has wide applicability on different types of tissues, materials, and cells. Moreover, histological analysis allows for multicolored labeling of tissue sections, providing functional information with high accuracy, specificity, and resolution. Yet, some imaging modalities have already shown to perform similar or even better in the characterization of cell functionality in specific samples. Depending on the application, location, and size of the tissue-engineered construct, a specific imaging modality could be chosen and optimized to obtain the desired information without the need to disrupt the sample.

Recent developments in multimodal imaging will help to overcome specific method-based limitations by combining the benefits of each individual imaging method. Furthermore, incorporation of sensor-based information can further move forward the comprehensiveness of retrieved information from a single sample during culture. One can think of cell localization and oxygen concentration by multimodal imaging within a $3 \mathrm{D}$ construct cultured in a bioreactor ${ }^{257}$ and subsequent cell functionality determination by detecting protein secretion with protein-specific circuitry integrated sensors. $^{258,259}$ Wireless nanoscale biosensors have been developed, which in theory could be incorporated within a scaffold, revealing information with a certain spatiotemporal resolution. ${ }^{260,261}$ Ultimately, these sensors could be combined with actuators, resulting in a responsive autonomous system capable of locally providing instructive signals.

Parameters that are currently already monitored by sensoractuator-based systems are $\mathrm{pH}$, oxygen saturation, and temperature. However, observing recent advances in sensoractuator technology, we think that protein secretion, surface marker expression, or even gene expression will be included in the next generation of targeted parameters.

The combination of this information could allow a tissue engineer to adapt its culture conditions while following the outcomes in real time. Ultimately, monitoring to automate production successfully would require integrated control systems with built-in data analysis and programmed parameter adaptations.

\section{Acknowledgment}

The authors gratefully acknowledge the funding from the Netherlands Institute for Regenerative Medicine (NIRM) through the grant number FES0908.

\section{Disclosure Statement}

No competing financial interests exist.

\section{References}

1. Doroski, D.M., Brink, K.S., and Temenoff, J.S. Techniques for biological characterization of tissue-engineered tendon and ligament. Biomaterials 28, 187, 2007. 
2. Santoro, R., Krause, C., Martin, I., and Wendt, D. On-line monitoring of oxygen as a non-destructive method to quantify cells in engineered 3D tissue constructs. J Tissue Eng Regen Med 6, 696, 2011.

3. Materna, T., Rolf, H.J., Napp, J., Schulz, J., Gelinsky, M., and Schliephake, H. In vitro characterization of threedimensional scaffolds seeded with human bone marrow stromal cells for tissue engineered growth of bone: mission impossible? A methodological approach. Clin Oral Implants Res 19, 379, 2008.

4. Mather, M.L., Morgan, S.P., and Crowe, J.A. Meeting the needs of monitoring in tissue engineering. Regen Med 2, 145, 2007.

5. Holmes, C., Tabrizian, M., and Bagnaninchi, P.O. Motility imaging via optical coherence phase microscopy enables labelfree monitoring of tissue growth and viability in 3D tissueengineering scaffolds. J Tissue Eng Regen Med 9, 641, 2013.

6. Olubamiji, A.D., Izadifar, Z., and Chen, D. Synchrotron imaging techniques for bone and cartilage tissue engineering: potentials, current trends, and future directions. Tissue Eng Part B Rev 20, 503, 2014.

7. Kotecha, M., Klatt, D., and Magin, R.L. Monitoring cartilage tissue engineering using magnetic resonance spectroscopy, imaging, and elastography. Tissue Eng Part B Rev 19, 470, 2013.

8. Matcher, S. Practical aspects of OCT imaging in tissue engineering. Methods Mol Biol 695, 261, 2011.

9. Smith, L.E., Smallwood, R., and Macneil, S. A comparison of imaging methodologies for 3D tissue engineering. Microsc Res Tech 73, 1123, 2010.

10. Ballyns, J.J., and Bonassar, L.J. Image-guided tissue engineering. J Cell Mol Med 13, 1428, 2009.

11. Belicchi, M., Cancedda, R., Cedola, A., Fiori, F., Gavina, M., Giuliani, A., et al. Some applications of nanotechnologies in stem cells research. Mater Sci Eng B Adv 165, 139, 2009.

12. Vielreicher, M., Schurmann, S., Detsch, R., Schmidt, M.A., Buttgereit, A., Boccaccini, A., et al. Taking a deep look: modern microscopy technologies to optimize the design and functionality of biocompatible scaffolds for tissue engineering in regenerative medicine. J R Soc Interface 10, 20130263, 2013.

13. Muller, W.E., Schroder, H.C., Shen, Z., Feng, Q., and Wang, X. Inorganic polymers: morphogenic inorganic biopolymers for rapid prototyping chain. Prog Mol Subcell Biol 54, 235, 2013.

14. Habibovic, P., Sees, T.M., van den Doel, M.A., van Blitterswijk, C.A., and de Groot, K. Osteoinduction by biomaterials-physicochemical and structural influences. J Biomed Mater Res 77, 747, 2006.

15. Habibovic, P., Yuan, H., van den Doel, M., Sees, T.M., van Blitterswijk, C.A., and de Groot, K. Relevance of osteoinductive biomaterials in critical-sized orthotopic defect. J Orthop Res 24, 867, 2006.

16. Yuan, H., Yang, Z., Li, Y., Zhang, X., De Bruijn, J.D., and De Groot, K. Osteoinduction by calcium phosphate biomaterials. J Mater Sci Mater Med 9, 723, 1998.

17. Dorozhkin, S.V. Biphasic, triphasic and multiphasic calcium orthophosphates. Acta Biomater 8, 963, 2012.

18. Li, J., Baker, B.A., Mou, X., Ren, N., Qiu, J., Boughton, R.I., et al. Biopolymer/calcium phosphate scaffolds for bone tissue engineering. Adv Healthc Mater 3, 469, 2014.

19. Santana, B.P., Nedel, F., Piva, E., de Carvalho, R.V., Demarco, F.F., and Carreno, N.L. Preparation, modifica- tion, and characterization of alginate hydrogel with nano-/ microfibers: a new perspective for tissue engineering. Biomed Res Int 2013, 307602, 2013.

20. Mo, X.T., Guo, S.C., Xie, H.Q., Deng, L., Zhi, W., Xiang, Z., et al. Variations in the ratios of co-cultured mesenchymal stem cells and chondrocytes regulate the expression of cartilaginous and osseous phenotype in alginate constructs. Bone 45, 42, 2009.

21. Chung, C., and Burdick, J.A. Influence of threedimensional hyaluronic acid microenvironments on mesenchymal stem cell chondrogenesis. Tissue Eng Part A 15, 243, 2009.

22. Di Martino, A., Sittinger, M., and Risbud, M.V. Chitosan: a versatile biopolymer for orthopaedic tissue-engineering. Biomaterials 26, 5983, 2005.

23. Camci-Unal, G., Cuttica, D., Annabi, N., Demarchi, D., and Khademhosseini, A. Synthesis and characterization of hybrid hyaluronic acid-gelatin hydrogels. Biomacromolecules 14, 1085, 2013.

24. Ferreira, A.M., Gentile, P., Chiono, V., and Ciardelli, G. Collagen for bone tissue regeneration. Acta Biomater 8, 3191, 2012.

25. McCullen, S.D., Miller, P.R., Gittard, S.D., Gorga, R.E., Pourdeyhimi, B., Narayan, R.J., et al. In situ collagen polymerization of layered cell-seeded electrospun scaffolds for bone tissue engineering applications. Tissue Eng Part C Methods 16, 1095, 2010.

26. Costa-Pinto, A.R., Reis, R.L., and Neves, N.M. Scaffolds based bone tissue engineering: the role of chitosan. Tissue Eng Part B Rev 17, 331, 2011.

27. Garcia-Fuentes, M., Meinel, A.J., Hilbe, M., Meinel, L., and Merkle, H.P. Silk fibroin/hyaluronan scaffolds for human mesenchymal stem cell culture in tissue engineering. Biomaterials 30, 5068, 2009.

28. Correia, C., Bhumiratana, S., Yan, L.P., Oliveira, A.L., Gimble, J.M., Rockwood, D., et al. Development of silkbased scaffolds for tissue engineering of bone from human adipose-derived stem cells. Acta Biomater 8, 2483, 2012.

29. Tamasan, M., Ozyegin, L.S., Oktar, F.N., and Simon, V. Characterization of calcium phosphate powders originating from Phyllacanthus imperialis and Trochidae Infundibulum concavus marine shells. Mater Sci Eng C Mater Biol Appl 33, 2569, 2013.

30. Peretz, H., Blinder, P., Segal, L., Baranes, D., and Vago, R. Aragonite crystalline matrix as an instructive microenvironment for neural development. J Tissue Eng Regen Med 2, 463, 2008.

31. Puvaneswary, S., Balaji Raghavendran, H.R., Ibrahim, N.S., Murali, M.R., Merican, A.M., and Kamarul, T. A comparative study on morphochemical properties and osteogenic cell differentiation within bone graft and coral graft culture systems. Int J Med Sci 10, 1608, 2013.

32. Viateau, V., Manassero, M., Sensebe, L., Langonne, A., Marchat, D., Logeart-Avramoglou, D., et al. Comparative study of the osteogenic ability of four different ceramic constructs in an ectopic large animal model. J Tissue Eng Regen Med 2013 [Epub ahead of print]; DOI: 10.1002/term.1782.

33. Nakayama, K.H., Batchelder, C.A., Lee, C.I., and Tarantal, A.F. Decellularized rhesus monkey kidney as a three-dimensional scaffold for renal tissue engineering. Tissue Eng 16, 2207, 2010.

34. Faulk, D.M., Johnson, S.A., Zhang, L., and Badylak, S.F. Role of the extracellular matrix in whole organ engineering. J Cell Physiol 229, 984, 2013. 
35. Ma, R., Li, M., Luo, J., Yu, H., Sun, Y., Cheng, S., et al. Structural integrity, ECM components and immunogenicity of decellularized laryngeal scaffold with preserved cartilage. Biomaterials 34, 1790, 2013.

36. Benders, K.E., van Weeren, P.R., Badylak, S.F., Saris, D.B., Dhert, W.J., and Malda, J. Extracellular matrix scaffolds for cartilage and bone regeneration. Trends Biotechnol 31, 169, 2013.

37. Badylak, S.F., Freytes, D.O., and Gilbert, T.W. Extracellular matrix as a biological scaffold material: structure and function. Acta Biomater 5, 1, 2009.

38. Partington, L., Mordan, N.J., Mason, C., Knowles, J.C., Kim, H.W., Lowdell, M.W., et al. Biochemical changes caused by decellularization may compromise mechanical integrity of tracheal scaffolds. Acta Biomater 9, 5251, 2013.

39. Sawkins, M.J., Bowen, W., Dhadda, P., Markides, H., Sidney, L.E., Taylor, A.J., et al. Hydrogels derived from demineralized and decellularized bone extracellular matrix. Acta Biomater 9, 7865, 2013.

40. Wolf, M.T., Daly, K.A., Brennan-Pierce, E.P., Johnson, S.A., Carruthers, C.A., D'Amore, A., et al. A hydrogel derived from decellularized dermal extracellular matrix. Biomaterials 33, 7028, 2012.

41. Seif-Naraghi, S.B., Horn, D., Schup-Magoffin, P.J., and Christman, K.L. Injectable extracellular matrix derived hydrogel provides a platform for enhanced retention and delivery of a heparin-binding growth factor. Acta Biomater 8, 3695, 2012.

42. Farnebo, S.J., Woon, C.Y., Schmitt, T., Joubert, L.M., Kim, M., Pham, H., et al. Design and characterization of an injectable tendon hydrogel: a scaffold for guided tissue regeneration in the musculoskeletal system. Tissue Eng 20, 1550, 2014

43. Iafiscol, M., Quirici, N., Foltran, I., and Rimondini, L. Electrospun collagen mimicking the reconstituted extracellular matrix improves osteoblastic differentiation onto titanium surfaces. J Nanosci Nanotechnol 13, 4720, 2013.

44. Lyu, S., Huang, C., Yang, H., and Zhang, X. Electrospun fibers as a scaffolding platform for bone tissue repair. J Orthop Res 31, 1382, 2013.

45. Hasan, A., Memic, A., Annabi, N., Hossain, M., Paul, A., Dokmeci, M.R., et al. Electrospun scaffolds for tissue engineering of vascular grafts. Acta Biomater 10, 11, 2014.

46. Tour, G., Wendel, M., and Tcacencu, I. Cell-derived matrix enhances osteogenic properties of hydroxyapatite. Tissue Eng 17, 127, 2011.

47. Thibault, R.A., Scott Baggett, L., Mikos, A.G., and Kasper, F.K. Osteogenic differentiation of mesenchymal stem cells on pregenerated extracellular matrix scaffolds in the absence of osteogenic cell culture supplements. Tissue Eng 16, 431, 2010.

48. Sadr, N., Pippenger, B.E., Scherberich, A., Wendt, D., Mantero, S., Martin, I., et al. Enhancing the biological performance of synthetic polymeric materials by decoration with engineered, decellularized extracellular matrix. Biomaterials 33, 5085, 2012.

49. Cheng, C.W., Solorio, L.D., and Alsberg, E. Decellularized tissue and cell-derived extracellular matrices as scaffolds for orthopaedic tissue engineering. Biotechnol Adv 32, 462, 2014.

50. Crapo, P.M., Gilbert, T.W., and Badylak, S.F. An overview of tissue and whole organ decellularization processes. Biomaterials 32, 3233, 2011.

51. Arenas-Herrera, J.E., Ko, I.K., Atala, A., and Yoo, J.J. Decellularization for whole organ bioengineering. Biomed Mater 8, 014106, 2013.
52. Song, J.J., and Ott, H.C. Organ engineering based on decellularized matrix scaffolds. Trends Mol Med 17, 424, 2011.

53. Liu, X., and Ma, P.X. Polymeric scaffolds for bone tissue engineering. Ann Biomed Eng 32, 477, 2004.

54. Puppi, D., Chiellini, F., Piras, A.M., and Chiellini, E. Polymeric materials for bone and cartilage repair. Prog Polym Sci 35, 403, 2010.

55. Lee, K.Y., and Mooney, D.J. Hydrogels for tissue engineering. Chem Rev 101, 1869, 2010.

56. Griffith, L.G., and Naughton, G. Tissue engineeringcurrent challenges and expanding opportunities. Science 295, 1009, 2002.

57. Chatterjee, K., Lin-Gibson, S., Wallace, W.E., Parekh, S.H., Lee, Y.J., Cicerone, M.T., et al. The effect of 3D hydrogel scaffold modulus on osteoblast differentiation and mineralization revealed by combinatorial screening. Biomaterials 31, 5051, 2010.

58. Buxton, A.N., Zhu, J., Marchant, R., West, J.L., Yoo, J.U., and Johnstone, B. Design and characterization of poly(ethylene glycol) photopolymerizable semi-interpenetrating networks for chondrogenesis of human mesenchymal stem cells. Tissue Eng 13, 2549, 2007.

59. Porter, J.R., Henson, A., and Popat, K.C. Biodegradable poly(epsilon-caprolactone) nanowires for bone tissue engineering applications. Biomaterials 30, 780, 2009.

60. Schuller-Ravoo, S., Teixeira, S.M., Feijen, J., Grijpma, D.W., and Poot, A.A. Flexible and elastic scaffolds for cartilage tissue engineering prepared by stereolithography using poly(trimethylene carbonate)-based resins. Macromol Biosci 13, 1711, 2013.

61. Peter, S.J., Miller, M.J., Yasko, A.W., Yaszemski, M.J., and Mikos, A.G. Polymer concepts in tissue engineering. J Biomed Mater Res 43, 422, 1998.

62. Anseth, K.S., Shastri, V.R., and Langer, R. Photopolymerizable degradable polyanhydrides with osteocompatibility. Nat Biotechnol 17, 156, 1999.

63. Jansen, E.J., Pieper, J., Gijbels, M.J., Guldemond, N.A., Riesle, J., Van Rhijn, L.W., et al. PEOT/PBT based scaffolds with low mechanical properties improve cartilage repair tissue formation in osteochondral defects. $\mathrm{J}$ Biomed Mater Res 89, 444, 2009.

64. Bose, S., Roy, M., and Bandyopadhyay, A. Recent advances in bone tissue engineering scaffolds. Trends Biotechnol 30, 546, 2012.

65. Mitchell, A., Kim, B., Cottrell, J., Snyder, S., Witek, L., Ricci, J., et al. Development of a guided bone regeneration device using salicylic acid-poly(anhydride-ester) polymers and osteoconductive scaffolds. J Biomed Mater Res Part A 102, 655, 2014.

66. Meyers, M.A., Chen, P.Y., Lin, A.Y.M., and Seki, Y. Biological materials: structure and mechanical properties. Prog Mater Sci 53, 1, 2008.

67. Scott, T.G., Blackburn, G., Ashley, M., Bayer, I.S., Ghosh, A., Biris, A.S., et al. Advances in bionanomaterials for bone tissue engineering. J Nanosci Nanotechnol 13, 1, 2013.

68. Nandakumar, A., Barradas, A., de Boer, J., Moroni, L., van Blitterswijk, C., and Habibovic, P. Combining technologies to create bioactive hybrid scaffolds for bone tissue engineering. Biomatter 3, pii: e23705, 2013.

69. Yang, Z., Wu, Y., Li, C., Zhang, T., Zou, Y., Hui, J.H., et al. Improved mesenchymal stem cells attachment and in vitro cartilage tissue formation on chitosan-modified poly(L-lactide-co-epsilon-caprolactone) scaffold. Tissue Eng 18, 242, 2012. 
70. Jin, R., Teixeira, L.S.M., Krouwels, A., Dijkstra, P.J., van Blitterswijk, C.A., Karperien, M., et al. Synthesis and characterization of hyaluronic acid-poly(ethylene glycol) hydrogels via Michael addition: an injectable biomaterial for cartilage repair. Acta Biomater 6, 1968, 2010.

71. Liu, S.Q., Tian, Q.A., Wang, L., Hedrick, J.L., Hui, J.H.P., Yang, Y.Y., et al. Injectable biodegradable poly(ethylene glycol)/RGD peptide hybrid hydrogels for in vitro chondrogenesis of human mesenchymal stem cells. Macromol Rapid Commun 31, 1148, 2010.

72. Marelli, B., Ghezzi, C.E., Barralet, J.E., Boccaccini, A.R., and Nazhat, S.N. Three-dimensional mineralization of dense nanofibrillar collagen-bioglass hybrid scaffolds. Biomacromolecules 11, 1470, 2010.

73. Moroni, L., Hamann, D., Paoluzzi, L., Pieper, J., de Wijn, J.R., van and Blitterswijk, C.A. Regenerating articular tissue by converging technologies. PLoS One 3, e3032, 2008.

74. Yeong, W.Y., Chua, C.K., Leong, K.F., and Chandrasekaran, M. Rapid prototyping in tissue engineering: challenges and potential. Trends Biotechnol 22, 643, 2004.

75. Weigel, T., Schinkel, G., and Lendlein, A. Design and preparation of polymeric scaffolds for tissue engineering. Expert Rev Med Devices 3, 835, 2006.

76. Akbarzadeh, R., and Yousefi, A.M. Effects of processing parameters in thermally induced phase separation technique on porous architecture of scaffolds for bone tissue engineering. J Biomed Mater Res Part B Appl Biomater 102, 1304, 2014.

77. Cao, Y., Mitchell, G., Messina, A., Price, L., Thompson, E., Penington, A., et al. The influence of architecture on degradation and tissue ingrowth into three-dimensional poly(lactic-co-glycolic acid) scaffolds in vitro and in vivo. Biomaterials 27, 2854, 2006.

78. Heijkants, R.G., van Calck, R.V., De Groot, J.H., Pennings, A.J., Schouten, A.J., van Tienen, T.G., et al. Design, synthesis and properties of a degradable polyurethane scaffold for meniscus regeneration. J Mater Sci Mater Med 15, 423, 2004.

79. Zhao, F., Yin, Y., Lu, W.W., Leong, J.C., Zhang, W., Zhang, J., et al. Preparation and histological evaluation of biomimetic three-dimensional hydroxyapatite/chitosan-gelatin network composite scaffolds. Biomaterials 23, 3227, 2002.

80. Jensen, J., Rolfing, J.H., Svend Le, D.Q., Kristiansen, A.A., Nygaard, J.V., Hokland, L.B., et al. Surfacemodified functionalized polycaprolactone scaffolds for bone repair: in vitro and in vivo experiments. J Biomed Mater Res 102, 2993, 2013.

81. Stokols, S., and Tuszynski, M.H. Freeze-dried agarose scaffolds with uniaxial channels stimulate and guide linear axonal growth following spinal cord injury. Biomaterials 27, 443, 2006.

82. Harley, B.A., Hastings, A.Z., Yannas, I.V., and Sannino, A. Fabricating tubular scaffolds with a radial pore size gradient by a spinning technique. Biomaterials 27, 866, 2006.

83. Claase, M.B., Grijpma, D.W., Mendes, S.C., De Bruijn, J.D., and Feijen, J. Porous PEOT/PBT scaffolds for bone tissue engineering: preparation, characterization, and in vitro bone marrow cell culturing. J Biomed Mater Res 64, 291, 2006.

84. Vaquette, C., Frochot, C., Rahouadj, R., and Wang, X. An innovative method to obtain porous PLLA scaffolds with highly spherical and interconnected pores. J Biomed Mater Res Part B Appl Biomater 86, 9, 2008.

85. Suh, S.W., Shin, J.Y., Kim, J., Kim, J., Beak, C.H., Kim, D.I., et al. Effect of different particles on cell proliferation in polymer scaffolds using a solvent-casting and particulate leaching technique. ASAIO J 48, 460, 2002.

86. Liao, C.J., Chen, C.F., Chen, J.H., Chiang, S.F., Lin, Y.J., and Chang, K.Y. Fabrication of porous biodegradable polymer scaffolds using a solvent merging/particulate leaching method. J Biomed Mater Res 59, 676, 2002.

87. Wei, G., and Ma, P.X. Macroporous and nanofibrous polymer scaffolds and polymer/bone-like apatite composite scaffolds generated by sugar spheres. J Biomed Mater Res 78, 306, 2006.

88. Karageorgiou, V., and Kaplan, D. Porosity of 3D biomaterial scaffolds and osteogenesis. Biomaterials 26, 5474, 2005.

89. Janeczek Portalska, K., Leferink, A., Groen, N., Fernandes, H., Moroni, L., van Blitterswijk, C., et al. Endothelial differentiation of mesenchymal stromal cells. PLoS One 7, e46842, 2012.

90. Lantada, A.D., and Morgado, P.L. Rapid prototyping for biomedical engineering: current capabilities and challenges. Annu Rev Biomed Eng 14, 73, 2012.

91. Hollister, S.J. Porous scaffold design for tissue engineering. Nat Mater 4, 518, 2012.

92. Mota, C., Puppi, D., Chiellini, F., and Chiellini, E. Additive manufacturing techniques for the production of tissue engineering constructs. J Tissue Eng Regen Med 9, 174, 2015.

93. Moroni, L., de Wijn, J.R., and van Blitterswijk, C.A. Three-dimensional fiber-deposited PEOT/PBT copolymer scaffolds for tissue engineering: influence of porosity, molecular network mesh size, and swelling in aqueous media on dynamic mechanical properties. J Biomed Mater Res 75, 957, 2005.

94. Kim, J., McBride, S., Tellis, B., Alvarez-Urena, P., Song, Y.H., Dean, D.D., et al. Rapid-prototyped PLGA/beta$\mathrm{TCP} /$ hydroxyapatite nanocomposite scaffolds in a rabbit femoral defect model. Biofabrication 4, 025003, 2012.

95. Landers, R., Hubner, U., Schmelzeisen, R., and Mulhaupt, R. Rapid prototyping of scaffolds derived from thermoreversible hydrogels and tailored for applications in tissue engineering. Biomaterials 23, 4437, 2002.

96. Cohen, D.L., Malone, E., Lipson, H., and Bonassar, L.J. Direct freeform fabrication of seeded hydrogels in arbitrary geometries. Tissue Eng 12, 1325, 2006.

97. Williams, J.M., Adewunmi, A., Schek, R.M., Flanagan, C.L., Krebsbach, P.H., Feinberg, S.E., et al. Bone tissue engineering using polycaprolactone scaffolds fabricated via selective laser sintering. Biomaterials 26, 4817, 2005.

98. Tan, K.H., Chua, C.K., Leong, K.F., Cheah, C.M., Gui, W.S., Tan, W.S., et al. Selective laser sintering of biocompatible polymers for applications in tissue engineering. Biomed Mater Eng 15, 113, 2005.

99. Niino, T., Hamajima, D., Montagne, K., Oizumi, S., Naruke, H., Huang, H., et al. Laser sintering fabrication of three-dimensional tissue engineering scaffolds with a flow channel network. Biofabrication 3, 034104, 2011.

100. Mazzoli, A. Selective laser sintering in biomedical engineering. Med Biol Eng Comput 51, 245, 2013.

101. Gittard, S.D., and Narayan, R.J. Laser direct writing of micro- and nano-scale medical devices. Expert Rev Med Devices 7, 343, 2010.

102. Schuller-Ravoo, S., Feijen, J., and Grijpma, D.W. Preparation of flexible and elastic poly(trimethylene carbonate) structures by stereolithography. Macromol Biosci 11, $1662,2010$. 
103. Cooke, M.N., Fisher, J.P., Dean, D., Rimnac, C., and Mikos, A.G. Use of stereolithography to manufacture critical-sized 3D biodegradable scaffolds for bone ingrowth. J Biomed Mater Res Part B Appl Biomater 64, 65, 2003.

104. Skoog, S.A., Goering, P.L., and Narayan, R.J. Stereolithography in tissue engineering. J Mater Sci Mater Med 25, 845, 2014.

105. Moroni, L., Licht, R., de Boer, J., de Wijn, J.R., and van Blitterswijk, C.A. Fiber diameter and texture of electrospun PEOT/PBT scaffolds influence human mesenchymal stem cell proliferation and morphology, and the release of incorporated compounds. Biomaterials 27, 4911, 2003.

106. Lannutti, J., Reneker, D., Ma, T., Tomasko, D., and Farson, D.F. Electrospinning for tissue engineering scaffolds. Mater Sci Eng C 27, 504, 2007.

107. Li, D., and Xia, Y.N. Electrospinning of nanofibers: reinventing the wheel? Adv Mater 16, 1151, 2004.

108. Kasuga, T., Sawada, M., Nogami, M., and Abe, Y. Bioactive ceramics prepared by sintering and crystallization of calcium phosphate invert glasses. Biomaterials 20, 1415, 1999.

109. Arita, I.H., Wilkinson, D.S., Mondragon, M.A., and Castano, V.M. Chemistry and sintering behaviour of thin hydroxyapatite ceramics with controlled porosity. Biomaterials 16, 403, 1995.

110. Rusnah, M., Andanastuti, M., and Idris, B. The influence of sintering temperature on the porosity and strength of porous hydroxyapatite ceramics. Med J Malaysia 59 Suppl B, 158, 2004.

111. Solchaga, L.A., Tognana, E., Penick, K., Baskaran, H., Goldberg, V.M., Caplan, A.I., et al. A rapid seeding technique for the assembly of large cell/scaffold composite constructs. Tissue Eng 12, 1851, 2006.

112. Harrison, B.S., Eberli, D., Lee, S.J., Atala, A., and Yoo, J.J. Oxygen producing biomaterials for tissue regeneration. Biomaterials 28, 4628, 2007.

113. Causa, F., Netti, P.A., and Ambrosio, L. A multifunctional scaffold for tissue regeneration: the need to engineer a tissue analogue. Biomaterials 28, 5093, 2007.

114. Du, Y., Ghodousi, M., Lo, E., Vidula, M.K., Emiroglu, O., and Khademhosseini, A. Surface-directed assembly of cell-laden microgels. Biotechnol Bioeng 105, 655, 2010.

115. Leferink, A., Schipper, D., Arts, E., Vrij, E., Rivron, N., Karperien, M., et al. Engineered micro-objects as scaffolding elements in cellular building blocks for bottomup tissue engineering approaches. Adv Mater 26, 2592, 2014.

116. Chen, T., Zhang, Z.L., and Glotzer, S.C. A precise packing sequence for self-assembled convex structures. Proc Natl Acad Sci U S A 104, 717, 2007.

117. Yanagawa, F., Kaji, H., Jang, Y.H., Bae, H., Yanan, D., Fukuda, J., et al. Directed assembly of cell-laden microgels for building porous three-dimensional tissue constructs. J Biomed Mater Res 97, 93, 2011.

118. Lee, H.S., Teng, S.W., Chen, H.C., Lo, W., Sun, Y., Lin, T.Y., et al. Imaging human bone marrow stem cell morphogenesis in polyglycolic acid scaffold by multiphoton microscopy. Tissue Eng 12, 2835, 2006.

119. Appel, A.A., Anastasio, M.A., Larson, J.C., and Brey, E.M. Imaging challenges in biomaterials and tissue engineering. Biomaterials 34, 6615, 2013.

120. Georgakoudi, I., Rice, W.L., Hronik-Tupaj, M., and Kaplan, D.L. Optical spectroscopy and imaging for the noninvasive evaluation of engineered tissues. Tissue Eng Part B Rev 14, 321, 2008.

121. Boyde, A., and Jones, S.J. Scanning electron microscopy of bone: instrument, specimen, and issues. Microsc Res Tech 33, 920, 1996.

122. Cai, X., Zhang, Y.S., Xia, Y., and Wang, L.V. Photoacoustic microscopy in tissue engineering. Mater Today 16, 67, 1996.

123. Mestres, P., Putz, N., de las Heras, S.G.G., Poblete, E.G., Morguet, A., and Laue, M. The surface topography of the choroid plexus. Environmental, low and high vacuum scanning electron microscopy. Ann Anat 193, 197, 2011.

124. McGregor, J.E., and Donald, A.M. The application of ESEM to biological samples. J Phys Conf Ser 1, 241, 2010.

125. Donald, A.M. The use of environmental scanning electron microscopy for imaging wet and insulating materials. Nat Mater 2, 511, 2003.

126. Doyle, V., Pearson, R., Lee, D., Wolowacz, S., and McTaggart, S. An investigation of the growth of human dermal fibroblasts on poly-L-lactic acid in vitro. J Mater Sci Mater Med 7, 381, 1996.

127. Yan, D., Jones, J., Yuan, X.Y., Xu, X.H., Sheng, J., Lee, J.C.M., et al. Plasma treatment of random and aligned electrospun PCL nanofibers. J Med Biol Eng 33, 171, 2013.

128. Soldani, P., Pellegrini, A., Gesi, M., Lenzi, P., Cristofani, R., and Paparelli, A. SEM/TEM investigation of rat cardiac subcellular alterations induced by changing duration of noise stress. Anat Rec 248, 521, 1997.

129. Machac, J. Cardiac positron emission tomography imaging. Semin Nucl Med 35, 17, 1997.

130. Talukdar, Y., Avti, P.K., Sun, J., and Sitharaman, B. Multimodal ultrasound-photoacoustic imaging of tissue engineering scaffolds and blood oxygen saturation in and around the scaffolds. Tissue Eng Part C Methods 20, 440, 2014.

131. Wolfs, E., Struys, T., Notelaers, T., Roberts, S.J., Sohni, A., Bormans, G., et al. 18F-FDG labeling of mesenchymal stem cells and multipotent adult progenitor cells for PET imaging: effects on ultrastructure and differentiation capacity. J Nucl Med 54, 447, 2013.

132. Chouinard, J.A., Rousseau, J.A., Beaudoin, J.F., Vermette, P., and Lecomte, R. Positron emission tomography detection of human endothelial cell and fibroblast monolayers: effect of pretreament and cell density on 18FDG uptake. Vasc Cell 4, 5, 2012.

133. Adonai, N., Nguyen, K.N., Walsh, J., Iyer, M., Toyokuni, T., Phelps, M.E., et al. Ex vivo cell labeling with 64Cu-pyruvaldehyde-bis(N4-methylthiosemicarbazone) for imaging cell trafficking in mice with positron-emission tomography. Proc Natl Acad Sci U S A 99, 3030, 2002.

134. Doyle, B., Kemp, B.J., Chareonthaitawee, P., Reed, C., Schmeckpeper, J., Sorajja, P., et al. Dynamic tracking during intracoronary injection of $18 \mathrm{~F}-\mathrm{FDG}$-labeled progenitor cell therapy for acute myocardial infarction. $\mathrm{J}$ Nucl Med 48, 1708, 2007.

135. Souron, J.B., Petiet, A., Decup, F., Tran, X.V., Lesieur, J., Poliard, A., et al. Pulp cell tracking by radionuclide imaging for dental tissue engineering. Tissue Eng Part C Methods 20, 188, 2014.

136. Polyak, A., Hajdu, I., Bodnar, M., Trencsenyi, G., Postenyi, Z., Haasz, V., et al. (99m)Tc-labelled nanosystem as tumour imaging agent for SPECT and SPECT/CT modalities. Int J Pharm 449, 10, 2014.

137. Belmar-Lopez, C., Mendoza, G., Oberg, D., Burnet, J., Simon, C., Cervello, I., et al. Tissue-derived mesenchymal 
stromal cells used as vehicles for anti-tumor therapy exert different in vivo effects on migration capacity and tumor growth. BMC Med 11, 139, 2013.

138. Koba, W., Kim, K., Lipton, M.L., Jelicks, L., Das, B., Herbst, L., et al. Imaging devices for use in small animals. Semin Nucl Med 41, 151, 2011.

139. Khmelinskii, A., Groen, H.C., Baiker, M., de Jong, M., and Lelieveldt, B.P. Segmentation and visual analysis of whole-body mouse skeleton microSPECT. PLoS One 7, e48976, 2012.

140. Jaiswal, M., Koul, V., Dinda, A.K., Mohanty, S., and Jain, K.G. Cell adhesion and proliferation studies on semiinterpenetrating polymeric networks (semi-IPNs) of polyacrylamide and gelatin. J Biomed Mater Res Part B Appl Biomater 98, 342, 2011.

141. Saeidi, N., Guo, X., Hutcheon, A.E., Sander, E.A., Bale, S.S., Melotti, S.A., et al. Disorganized collagen scaffold interferes with fibroblast mediated deposition of organized extracellular matrix in vitro. Biotechnol Bioeng 109, 2683, 2012.

142. Friedl, P. Dynamic imaging of cellular interactions with extracellular matrix. Histochem Cell Biol 122, 183, 2004.

143. Quentmeier, S., Denicke, S., and Gericke, K.H. Two-color two-photon fluorescence laser scanning microscopy. J Fluoresc 19, 1037, 2009.

144. Martin, I., Mastrogiacomo, M., De Leo, G., Muraglia, A., Beltrame, F., Cancedda, R., et al. Fluorescence microscopy imaging of bone for automated histomorphometry. Tissue Eng 8, 847, 2002.

145. Calle, E.A., Vesuna, S., Dimitrievska, S., Zhou, K., Huang, A., Zhao, L., et al. The use of optical clearing and multiphoton microscopy for investigation of threedimensional tissue-engineered constructs. Tissue Eng Part C Methods 2014.

146. Turchin, I.V., Kamensky, V.A., Plehanov, V.I., Orlova, A.G., Kleshnin, M.S., Fiks, I.I., et al. Fluorescence diffuse tomography for detection of red fluorescent protein expressed tumors in small animals. J Biomed Opt 13, 041310, 2008.

147. Farwell, D.G., Meier, J.D., Park, J., Sun, Y., Coffman, H., Poirier, B., et al. Time-resolved fluorescence spectroscopy as a diagnostic technique of oral carcinoma: validation in the hamster buccal pouch model. Arch Otolaryngol Head Neck Surg 136, 126, 2010.

148. Wagnieres, G.A., Star, W.M., and Wilson, B.C. In vivo fluorescence spectroscopy and imaging for oncological applications. Photochem Photobiol 68, 603, 1998.

149. Leblond, F., Davis, S.C., Valdes, P.A., and Pogue, B.W. Pre-clinical whole-body fluorescence imaging: review of instruments, methods and applications. J Photochem Photobiol B Biol 98, 77, 2010.

150. Yang, M., Jiang, P., and Hoffman, R.M. Whole-body subcellular multicolor imaging of tumor-host interaction and drug response in real time. Cancer Res 67, 5195, 2007.

151. Steyer, G.J., Roy, D., Salvado, O., Stone, M.E., and Wilson, D.L. Cryo-imaging of fluorescently-labeled single cells in a mouse. Proc SPIE Int Soc Opt Eng 7262, 72620W, 2009.

152. Cowles, E.A., Kovar, J.L., Curtis, E.T., Xu, H., and Othman, S.F. Near-infrared optical imaging for monitoring the regeneration of osteogenic tissue-engineered constructs. Biores Open Access 2, 186, 2013.

153. Kim, S.H., Lee, J.H., Hyun, H., Ashitate, Y., Park, G., Robichaud, K., et al. Near-infrared fluorescence imaging for noninvasive trafficking of scaffold degradation. Sci Rep 3, 1198, 2013.

154. de Mel, A., Oh, J.T., Ramesh, B., and Seifalian, A.M. Biofunctionalized quantum dots for live monitoring of stem cells: applications in regenerative medicine. Regen Med 7, 335, 2012.

155. Yang, M., Baranov, E., Jiang, P., Sun, F.X., Li, X.M., Li, L.N., et al. Whole-body optical imaging of green fluorescent protein-expressing tumors and metastases. Proc Natl Acad Sci U S A 97, 1206, 2000.

156. Bouvet, M., and Hoffman, R.M. Tumor imaging technologies in mouse models. Methods Mol Biol 1267, 3218, 2015.

157. Suetsugu, A., Momiyama, M., Hiroshima, Y., Shimizu, M., Saji, S., Moriwaki, H., et al. Color-coded imaging of breast cancer metastatic niche formation in nude mice. J Cell Biochem 116, 2730, 2015.

158. Hoffman, R.M. Application of GFP imaging in cancer. Lab Invest 95, 432, 2015.

159. Hoover, E.E., and Squier, J.A. Advances in multiphoton microscopy technology. Nat Photon 7, 93, 2013.

160. Kluge, J.A., Leisk, G.G., Cardwell, R.D., Fernandes, A.P., House, M., Ward, A., et al. Bioreactor system using noninvasive imaging and mechanical stretch for biomaterial screening. Ann Biomed Eng 39, 1390, 2011.

161. Campagnola, P.J., Millard, A.C., Terasaki, M., Hoppe, P.E., Malone, C.J., and Mohler, W.A. Three-dimensional high-resolution second-harmonic generation imaging of endogenous structural proteins in biological tissues. Biophys J 82, 493, 2002.

162. Sun, Y., Tan, H.Y., Lin, S.J., Lee, H.S., Lin, T.Y., Jee, S.H., et al. Imaging tissue engineering scaffolds using multiphoton microscopy. Microsc Res Tech 71, 140, 2008.

163. Schenke-Layland, K., Riemann, I., Damour, O., Stock, U.A., and Konig, K. Two-photon microscopes and in vivo multiphoton tomographs-powerful diagnostic tools for tissue engineering and drug delivery. Adv Drug Deliv Rev 58, 878, 2008.

164. Pena, A.M., Fagot, D., Olive, C., Michelet, J.F., Galey, J.B., Leroy, F., et al. Multiphoton microscopy of engineered dermal substitutes: assessment of 3-D collagen matrix remodeling induced by fibroblast contraction. J Biomed Opt 15, 056018, 2010.

165. Rice, W.L., Firdous, S., Gupta, S., Hunter, M., Foo, C.W., Wang, Y., et al. Non-invasive characterization of structure and morphology of silk fibroin biomaterials using nonlinear microscopy. Biomaterials 29, 2015, 2008.

166. Mouras, R., Bagnaninchi, P.O., Downes, A.R., and Elfick, A.P.D. Label-free assessment of adipose-derived stem cell differentiation using coherent anti-Stokes Raman scattering and multiphoton microscopy. J Biomed Opt 17, 116011, 2012.

167. Contag, C.H., and Bachmann, M.H. Advances in in vivo bioluminescence imaging of gene expression. Annu Rev Biomed Eng 4, 235, 2002.

168. Liu, J., Hilderink, J., Groothuis, T.A., Otto, C., van Blitterswijk, C.A., and de Boer, J. Monitoring nutrient transport in tissue-engineered grafts. J Tissue Eng Regen Med 9, 952, 2015.

169. Kammili, R.K., Taylor, D.G., Xia, J., Osuala, K., Thompson, K., Menick, D.R., et al. Generation of novel reporter stem cells and their application for molecular imaging of cardiac-differentiated stem cells in vivo. Stem Cells Dev 19, 1437, 2010. 
170. Blum, J.S., Temenoff, J.S., Park, H., Jansen, J.A., Mikos, A.G., and Barry, M.A. Development and characterization of enhanced green fluorescent protein and luciferase expressing cell line for non-destructive evaluation of tissue engineering constructs. Biomaterials 25, 5809, 2004.

171. Leo, B.M., Li, X.D., Balian, G., and Anderson, D.G. In vivo bioluminescent imaging of virus-mediated gene transfer and transduced cell transplantation in the intervertebral disc. Spine 29, 838, 2004.

172. Bar, I., Zilberman, Y., Zeira, E., Galun, E., Honigman, A., Turgeman, G., et al. Molecular imaging of the skeleton: quantitative real-time bioluminescence monitoring gene expression in bone repair and development. J Bone Miner Res 18, 570, 2003.

173. Roman, I., Vilalta, M., Rodriguez, J., Matthies, A.M., Srouji, S., Livne, E., et al. Analysis of progenitor cellscaffold combinations by in vivo non-invasive photonic imaging. Biomaterials 28, 2718, 2007.

174. Logeart-Avramoglou, D., Oudina, K., Bourguignon, M., Delpierre, L., Nicola, M.A., Bensidhoum, M., et al. In vitro and in vivo bioluminescent quantification of viable stem cells in engineered constructs. Tissue Eng Part C Methods 16, 447, 2010.

175. Olivo, C., Alblas, J., Verweij, V., Van Zonneveld, A.J., Dhert, W.J., and Martens, A.C. In vivo bioluminescence imaging study to monitor ectopic bone formation by luciferase gene marked mesenchymal stem cells. J Orthop Res 26, 901, 2008.

176. de Boer, J., van Blitterswijk, C., and Lowik, C. Bioluminescent imaging: emerging technology for non-invasive imaging of bone tissue engineering. Biomaterials 27, 1851, 2006.

177. Clemens, T.L., Tang, H., Maeda, S., Kesterson, R.A., Demayo, F., Pike, J.W., et al. Analysis of osteocalcin expression in transgenic mice reveals a species difference in vitamin D regulation of mouse and human osteocalcin genes. J Bone Miner Res 12, 1570, 1997.

178. Bago, J.R., Aguilar, E., Alieva, M., Soler-Botija, C., Vila, O.F., Claros, S., et al. In vivo bioluminescence imaging of cell differentiation in biomaterials: a platform for scaffold development. Tissue Eng 19, 593, 2013.

179. Huang, D., Swanson, E.A., Lin, C.P., Schuman, J.S., Stinson, W.G., Chang, W., et al. Optical coherence tomography. Science 254, 1178, 1991.

180. Yang, Y., Dubois, A., Qin, X.P., Li, J., El Haj, A., and Wang, R.K. Investigation of optical coherence tomography as an imaging modality in tissue engineering. Phys Med Biol 51, 1649, 2006.

181. Liang, X., Graf, B.W., and Boppart, S.A. Imaging engineered tissues using structural and functional optical coherence tomography. J Biophoton 2, 643, 2009.

182. Graf, B.W., and Boppart, S.A. Imaging and analysis of three-dimensional cell culture models. Methods Mol Biol 591, 211, 2010.

183. Yang, Y., Bagnaninchi, P.O., Cunha-Reis, C., Aydin, H.M., Piskin, E., and El Haj, A. Characterisation of scaffold architecture by optical coherence tomographyart. no. 64390G. Proc Soc Photo Opt Instrum 6439, G4390, 2007.

184. Ozturk, M.S., Lee, V.K., Zhao, L., Dai, G., and Intes, X. Mesoscopic fluorescence molecular tomography of reporter genes in bioprinted thick tissue. J Biomed Opt 18, 100501, 2013.
185. Tan, W., Sendemir-Urkmez, A., Fahrner, L.J., Jamison, R., Leckband, D., and Boppart, S.A. Structural and functional optical imaging of three-dimensional engineered tissue development. Tissue Eng 10, 1747, 2004.

186. Wang, Z.G., Pan, H., Yuan, Z.J., Liu, J.X., Chen, W.L., and Pan, Y.T. Assessment of dermal wound repair after collagen implantation with optical coherence tomography. Tissue Eng Part C Methods 14, 35, 2008.

187. Bagnaninchi, P.O., El Haj, A., and Yang, Y. Continuous monitoring of tissue growth inside a perfusion bioreactor by optical coherence tomography-art. no. 643903. Proc Soc Photo Opt Instrum 6439, 43903, 2007.

188. Mason, C., Markusen, J.F., Town, M.A., Dunnill, P., and Wang, R.K. Doppler optical coherence tomography for measuring flow in engineered tissue. Biosens Bioelectron 20, 414, 2004.

189. Tomlins, P.H., Wang, Y., Zhang, B., Tedaldi, M., and Tomlins, P.E. Complex flow characterisation of a porous tissue scaffold measured by Doppler optical coherence tomography. Proc SPIE 3, 6858, 2008.

190. Boppart, S.A. Advanced spectroscopic coherence tomography. Lasers and Electro-Optics Society, 2006. 19th Annual Meeting of the IEEE 2006, pp. 162-163.

191. Dunkers, J.P., Lee, Y.J., and Chatterjee, K. Single cell viability measurements in 3D scaffolds using in situ label free imaging by optical coherence microscopy. Biomaterials 33, 2119, 2012.

192. Kunstar, A., Leferink, A.M., Okagbare, P.I., Morris, M.D., Roessler, B.J., Otto, C., et al. Label-free Raman monitoring of extracellular matrix formation in threedimensional polymeric scaffolds. J R Soc Interface 10, 20130464, 2013.

193. Brauchle, E., and Schenke-Layland, K. Raman spectroscopy in biomedicine-non-invasive in vitro analysis of cells and extracellular matrix components in tissues. Biotechnol J 8, 288, 2013.

194. Notingher, I., Verrier, S., Romanska, H., Bishop, A.E., Polak, J.M., and Hench, L.L. In situ characterisation of living cells by Raman spectroscopy. Spectrosc Int J 16, 43, 2002.

195. Chan, J.W., Lieu, D.K., Huser, T., and Li, R.A. Label-free separation of human embryonic stem cells and their cardiac derivatives using Raman spectroscopy. Anal Chem 81, 1324, 2009.

196. Schulze, H.G., Konorov, S.O., Caron, N.J., Piret, J.M., Blades, M.W., and Turner, R.F.B. Assessing differentiation status of human embryonic stem cells noninvasively using Raman microspectroscopy. Anal Chem 82, 5020, 2010.

197. Leikin, S., Parsegian, V.A., Yang, W.H., and Walrafen, G.E. Raman spectral evidence for hydration forces between collagen triple helices. Proc Natl Acad Sci U S A 94, 11312, 1997.

198. Ellis, R., Green, E., and Winlove, C.P. Structural analysis of glycosaminoglycans and proteoglycans by means of Raman microspectrometry. Connect Tissue Res 50, 29, 2009.

199. Kunstar, A., Leijten, J., van Leuveren, S., Hilderink, J., Otto, C., van Blitterswijk, C.A., et al. Recognizing different tissues in human fetal femur cartilage by label-free Raman microspectroscopy. J Biomed Opt 17, 116012, 2012.

200. Jones, J.R., Vats, A., Notingher, L., Gough, J.E., Tolley, N.S., Polak, J.M., et al. In situ monitoring of chondrocyte 
response to bioactive scaffolds using Raman spectroscopy. Key Eng Mat 284-286, 623, 2005.

201. Boyd, A.R., Burke, G.A., and Meenan, B.J. Monitoring cellular behaviour using Raman spectroscopy for tissue engineering and regenerative medicine applications. J Mater Sci Mater Med 21, 2317, 2010.

202. Mather, M.L., Crowe, J.A., Morgan, S.P., White, L.J., Kalashnikov, A.N., Ivchenko, V.G., et al. Ultrasonic monitoring of foamed polymeric tissue scaffold fabrication. J Mater Sci Mater Med 19, 3071, 2008.

203. Kim, K., Jeong, C.G., and Hollister, S.J. Non-invasive monitoring of tissue scaffold degradation using ultrasound elasticity imaging. Acta Biomater 4, 783, 2008.

204. Rice, M.A., Waters, K.R., and Anseth, K.S. Ultrasound monitoring of cartilaginous matrix evolution in degradable PEG hydrogels. Acta Biomater 5, 152, 2009.

205. Kreitz, S., Dohmen, G., Hasken, S., Schmitz-Rode, T., Mela, P., and Jockenhoevel, S. Nondestructive method to evaluate the collagen content of fibrin-based tissue engineered structures via ultrasound. Tissue Eng Part C Methods 17, 1021, 2011.

206. Fite, B.Z., Decaris, M., Sun, Y., Sun, Y., Lam, A., Ho, C.K., et al. Noninvasive multimodal evaluation of bioengineered cartilage constructs combining timeresolved fluorescence and ultrasound imaging. Tissue Eng Part C Methods 17, 495, 2011.

207. Hu, S., and Wang, L.V. Neurovascular photoacoustic tomography. Front Neuroenerget 2, 10, 2010.

208. Saha, R.K., and Kolios, M.C. Effects of erythrocyte oxygenation on optoacoustic signals. J Biomed Opt 16, 115003, 2011.

209. Zhang, H.F., Maslov, K., Stoica, G., and Wang, L.V. Functional photoacoustic microscopy for high-resolution and noninvasive in vivo imaging. Nat Biotechnol 24, 848, 2006.

210. Needles, A., Heinmiller, A., Sun, J., Theodoropoulos, C., Bates, D., Hirson, D., et al. Development and initial application of a fully integrated photoacoustic microultrasound system. IEEE Trans Ultrason Ferroelectr Freq Control 60, 888, 2013.

211. Krumholz, A., Shcherbakova, D.M., Xia, J., Wang, L.V., and Verkhusha, V.V. Multicontrast photoacoustic in vivo imaging using near-infrared fluorescent proteins. Sci Rep 4, 3939, 2014.

212. Wang, L.H.V., and $\mathrm{Hu}, \mathrm{S}$. Photoacoustic tomography: in vivo imaging from organelles to organs. Science 335, 1458, 2012.

213. Cai, X., Li, L., Krumholz, A., Guo, Z., Erpelding, T.N., Zhang, C., et al. Multi-scale molecular photoacoustic tomography of gene expression. PLoS One 7, e43999, 2012.

214. Zhang, Y.S., Cai, X., Yao, J., Xing, W., Wang, L.V., and $\mathrm{Xia}, \mathrm{Y}$. Non-invasive and in situ characterization of the degradation of biomaterial scaffolds by volumetric photoacoustic microscopy. Angew Chem Int Ed Engl 53, 184, 2014.

215. Wang, L.V. Multiscale photoacoustic microscopy and computed tomography. Nat Photon 3, 503, 2009.

216. Cai, X., Paratala, B.S., Hu, S., Sitharaman, B., and Wang, L.V. Multiscale photoacoustic microscopy of singlewalled carbon nanotube-incorporated tissue engineering scaffolds. Tissue Eng Part C Methods 18, 310, 2012.

217. Zhang, Y., Cai, X., Choi, S.W., Kim, C., Wang, L.V., and Xia, Y. Chronic label-free volumetric photoacoustic mi- croscopy of melanoma cells in three-dimensional porous scaffolds. Biomaterials 31, 8651, 2010.

218. Aguirre, A., Guo, P., Gamelin, J., Yan, S., Sanders, M.M., Brewer, M., et al. Coregistered three-dimensional ultrasound and photoacoustic imaging system for ovarian tissue characterization. J Biomed Opt 14, 054014, 2009.

219. Feldkamp, L.A., Goldstein, S.A., Parfitt, A.M., Jesion, G., and Kleerekoper, M. The direct examination of threedimensional bone architecture in vitro by computed tomography. J Bone Miner Res 4, 3, 1989.

220. Kerckhofs, G., Sainz, J., Wevers, M., Van de Putte, T., and Schrooten, J. Contrast-enhanced nanofocus computed tomography images the cartilage subtissue architecture in three dimensions. Eur Cell Mater 25, 1799, 2013.

221. Baino, F., and Vitale-Brovarone, C. Three-dimensional glass-derived scaffolds for bone tissue engineering: current trends and forecasts for the future. J Biomed Mater Res 97, 514, 2011.

222. Meleo, D., Bedini, R., Pecci, R., Mangione, F., and Pacifici, L. Microtomographic and morphometric characterization of a bioceramic bone substitute in dental implantology. Ann Ist Super Sanita 48, 59, 2012.

223. Barbetta, A., Bedini, R., Pecci, R., and Dentini, M. Role of $\mathrm{X}$-ray microtomography in tissue engineering. Ann Ist Super Sanita 48, 10, 2012.

224. Dorsey, S.M., Lin-Gibson, S., and Simon, C.G., Jr. X-ray microcomputed tomography for the measurement of cell adhesionand proliferation in polymer scaffolds. Biomaterials 30, 2967, 2009.

225. Jones, G.L., Walton, R., Czernuszka, J., Griffiths, S.L., El Haj, A.J., and Cartmell, S.H. Primary human osteoblast culture on 3D porous collagen-hydroxyapatite scaffolds. J Biomed Mater Res 94, 1244, 2010.

226. Voronov, R.S., VanGordon, S.B., Shambaugh, R.L., Papavassiliou, D.V., and Sikavitsas, V.I. 3D tissue-engineered construct analysis via conventional high-resolution microcomputed tomography without X-ray contrast. Tissue Eng Part C Methods 19, 327, 2013.

227. Appel, A., Anastasio, M.A., and Brey, E.M. Potential for imaging engineered tissues with $\mathrm{X}$-ray phase contrast. Tissue Eng Part B Rev 17, 321, 2011.

228. Zhu, N., Chapman, D., Cooper, D., Schreyer, D.J., and Chen, X. X-ray diffraction enhanced imaging as a novel method to visualize low-density scaffolds in soft tissue engineering. Tissue Eng Part C Methods 17, 1071, 2011.

229. Xu, H.H., Othman, S.F., and Magin, R.L. Monitoring tissue engineering using magnetic resonance imaging. J Biosci Bioeng 106, 515, 2008.

230. Yang, C.Y., Hsiao, J.K., Tai, M.F., Chen, S.T., Cheng, H.Y., Wang, J.L., et al. Direct labeling of hMSC with SPIO: the long-term influence on toxicity, chondrogenic differentiation capacity, and intracellular distribution. Mol Imaging Biol 13, 443, 2011.

231. Kubinova, S., and Sykova, E. Nanotechnologies in regenerative medicine. Minim Invasive Ther Allied Technol 19, 144, 2010.

232. Di Corato, R., Gazeau, F., Le Visage, C., Fayol, D., Levitz, P., Lux, F., et al. High-resolution cellular MRI: gadolinium and iron oxide nanoparticles for in-depth dual-cell imaging of engineered tissue constructs. ACS Nano 7, 7500, 2013.

233. Narayan, S., Huang, F.P., Johnson, D., Gargesha, M., Flask, C.A., Zhang, G.Q., et al. Fast lipid and water levels by extraction with spatial smoothing (FLAWLESS): 
three-dimensional volume fat/water separation at 7 Tesla. J Magn Reson Imaging 33, 1464, 2011.

234. Lalande, C., Miraux, S., Derkaoui, S.M., Mornet, S., Bareille, R., Fricain, J.C., et al. Magnetic resonance imaging tracking of human adipose derived stromal cells within three-dimensional scaffolds for bone tissue engineering. Eur Cells Mater 21, 341, 2011.

235. Xu, H.H., Othman, S.F., Hong, L., Peptan, I.A., and Magin, R.L. Magnetic resonance microscopy for monitoring osteogenesis in tissue-engineered construct in vitro. Phys Med Biol 51, 719, 2006.

236. Peptan, I.A., Hong, L., Xu, H.H., and Magin, R.L. MR assessment of osteogenic differentiation in tissueengineered constructs. Tissue Eng 12, 843, 2006.

237. Hong, L., Peptan, I.A., Xu, H.H., and Magin, R.L. Nondestructive evaluation of osteogenic differentiation in tissue-engineered constructs. J Orthop Res 24, 889, 2006.

238. Miyata, S., Numano, T., Tateishic, T., and Ushida, T. Feasibility of noninvasive evaluation of biophysical properties of tissue-engineered cartilage by using quantitative MRI. J Biomech 40, 2990, 2007.

239. Leferink, A.M., Fratila, R.M., Koenrades, M.A., van Blitterswijk, C.A., Velders, A., and Moroni, L. An open source image processing method to quantitatively assess tissue growth after non-invasive magnetic resonance imaging in human bone marrow stromal cell seeded 3D polymeric scaffolds. PLoS One 9, e115000, 2014.

240. Washburn, N.R., Weir, M., Anderson, P., and Potter, K. Bone formation in polymeric scaffolds evaluated by proton magnetic resonance microscopy and X-ray microtomography. J Biomed Mater Res Part A 69A, 738, 2004.

241. Chesnick, I.E., Mason, J.T., Giuseppetti, A.A., Eidelman, N., and Potter, K. Magnetic resonance microscopy of collagen mineralization. Biophys J 95, 2017, 2008.

242. Nissi, M.J., Rieppo, J., Toyras, J., Laasanen, M.S., Kiviranta, I., Jurvelin, J.S., et al. T(2) relaxation time mapping reveals age- and species-related diversity of collagen network architecture in articular cartilage. Osteoarthritis Cartilage 14, 1265, 2006.

243. Xia, Y., Moody, J.B., Burton-Wurster, N., and Lust, G. Quantitative in situ correlation between microscopic MRI and polarized light microscopy studies of articular cartilage. Osteoarthritis Cartilage 9, 393, 2001.

244. Mountain, K.M., Bjarnason, T.A., Dunn, J.F., and Matyas, J.R. The functional microstructure of tendon collagen revealed by high-field MRI. Magn Reson Med 66, 520, 2011.

245. Crowe, J.J., Grant, S.C., Logan, T.M., and Ma, T. A magnetic resonance-compatible perfusion bioreactor system for three-dimensional human mesenchymal stem cell construct development. Chem Eng Sci 66, 4138, 2011.

246. Gottwald, E., Kleintschek, T., Giselbrecht, S., Truckenmuller, R., Altmann, B., Worgull, M., et al. Characterization of a chip-based bioreactor for three-dimensional cell cultivation via magnetic resonance imaging. Z Med Phys 23, 102, 2013.

247. Ramaswamy, S., Greco, J.B., Uluer, M.C., Zhang, Z.J., Zhang, Z.L., Fishbein, K.W., et al. Magnetic resonance imaging of chondrocytes labeled with superparamagnetic iron oxide nanoparticles in tissue-engineered cartilage. Tissue Eng Part A 15, 3899, 2009.

248. Feng, Y., Jin, X., Dai, G., Liu, J., Chen, J., and Yang, L. In vitro targeted magnetic delivery and tracking of su- perparamagnetic iron oxide particles labeled stem cells for articular cartilage defect repair. J Huazhong Univ Sci Technolog Med Sci 31, 204, 2011.

249. Tran, L.A., Krishnamurthy, R., Muthupillai, R., CabreiraHansen Mda, G., Willerson, J.T., Perin, E.C., et al. Gadonanotubes as magnetic nanolabels for stem cell detection. Biomaterials 31, 9482, 2010.

250. Ferreira, L. Nanoparticles as tools to study and control stem cells. J Cell Biochem 108, 746, 2009.

251. Bhirde, A., Xie, J., Swierczewska, M., and Chen, X. Nanoparticles for cell labeling. Nanoscale 3, 142, 2011.

252. Hachani, R., Lowdell, M., Birchall, M., and Thanh, N.T.K. Tracking stem cells in tissue-engineered organs using magnetic nanoparticles. Nanoscale 5, 11362, 2013.

253. Yang, C.Y., Tai, M.F., Chen, S.T., Wang, Y.T., Chen, Y.F., Hsiao, J.K., et al. Labeling of human mesenchymal stem cell: comparison between paramagnetic and superparamagnetic agents. J Appl Phys 105, 07B314, 2009.

254. Harrington, J.K., Chahboune, H., Criscione, J.M., Li, A.Y., Hibino, N., Yi, T., et al. Determining the fate of seeded cells in venous tissue-engineered vascular grafts using serial MRI. FASEB J 25, 4150, 2011.

255. Kraitchman, D.L., Gilson, W.D., and Lorenz, C.H. Stem cell therapy: MRI guidance and monitoring. J Magn Reson Imaging 27, 299, 2008.

256. Nitzsche, H., Metz, H., Lochmann, A., Bernstein, A., Hause, G., Groth, T., et al. Characterization of scaffolds for tissue engineering by benchtop-magnetic resonance imaging. Tissue Eng Part C Methods 15, 513, 2009.

257. Wang, L., Acosta, M.A., Leach, J.B., and Carrier, R.L. Spatially monitoring oxygen level in 3D microfabricated cell culture systems using optical oxygen sensing beads. Lab Chip 13, 1586, 2013.

258. Dvir, T., Timko, B.P., Kohane, D.S., and Langer, R. Nanotechnological strategies for engineering complex tissues. Nat Nanotechnol 6, 13, 2011.

259. Stern, E., Klemic, J.F., Routenberg, D.A., Wyrembak, P.N., Turner-Evans, D.B., Hamilton, A.D., et al. Labelfree immunodetection with CMOS-compatible semiconducting nanowires. Nature 445, 519, 2007.

260. Duan, X., Fu, T.M., Liu, J., and Lieber, C.M. Nanoelectronics-biology frontier: from nanoscopic probes for action potential recording in live cells to threedimensional cyborg tissues. Nano Today 8, 351, 2013.

261. Tian, B., Liu, J., Dvir, T., Jin, L., Tsui, J.H., Qing, Q., et al. Macroporous nanowire nanoelectronic scaffolds for synthetic tissues. Nat Mater 11, 986, 2012.

Address correspondence to: Anne M. Leferink, PhD BIOS/Lab-on-a-chip Group MIRA Institute

University of Twente Enschede $7522 \mathrm{NB}$ The Netherlands

E-mail: a.m.leferink@utwente.nl

Received: July 23, 2015 Accepted: January 11, 2016 Online Publication Date: March 1, 2016 